\title{
THE REGULATION OF FINANCIAL MARKETS AND THE EUROPEAN SOCIAL MODEL
}

\author{
Luis M. Hinojosa Martínez
}

\section{Introduction}

The regulation of financial markets generates very relevant consequences for inequality and produces important distributional effects. First, public funds used to restore financial stability and to rescue troubled financial institutions cannot be assigned to finance better infrastructures or health care. Second, financial crises destabilize productive industries, reduce investment and increase unemployment, deteriorating more sharply the welfare of the weaker sections of the population. Third, depending on the regulatory framework, consumers and retail investors may see their position weakened or suffer unexpected losses more easily. Thus it is obvious that the regulation of financial markets significantly conditions the social model.

For the purposes of this chapter, it is not necessary to determine precisely if there exist one or several European social models. There is a rich scholarly debate ${ }^{1}$ on the content of this expression that could lead us to identify some differences between European countries, but also some common features: universal education and ample coverage of public health services, wide unemployment benefits (compared to the US or the Asian countries), strong presence of the state in the marketplace guaranteeing the defense of public interests, and an independent judicial system that protects fundamental rights (including consumer rights). It is in relation to these common characteristics that we refer to the European social model. This setting suffices to frame our research on the distributional effects of financial market regulation, its fairness and its consequences for the maximization of social welfare in Europe. More specifically, we try to find out whether the reform of financial market regulation in the last decade has eroded the European social model or, rather on the contrary, contributed to safeguarding its main achievements. $^{2}$

\footnotetext{
${ }^{1}$ Adnett and Hardy distinguish in post-war Western Europe four main social models: the traditional model (few labor regulations and redistributive mechanisms with religious entities and family substituting state's social services in many instances), the liberal-individualist model (flexible labor markets, conditioned unemployment allowances and supremacy of freedom of contract), the Romano-Germanic legal tradition (strong market and labor regulation with almost universal social safety nets as regards health care and redistribution of income), and the social democratic model (strong protection of workers, tripartite decision-making in the marketplace and universal social benefits) (Nick Adnett/ Stephen Hardy, The European Social Model. Modernisation or Evolution (Edward Elgar 2005) 21-29). For a debate on the notion of European Social Model see Steve Corbett/ Alan Walker, 'Between Neoliberalism and Nationalist Populism: What Role for the 'European Social Model' and Social Quality in Post-Brexit Europe?', 18(1) Social Policy and Society 93-106 (2019); Rafael Muñoz de Bustillo Llorente, 'Crisis, Post-crisis y Estado de Bienestar: ¿hacia dónde transita el Modelo Social Europeo?', 54 Cuadernos Europeos de Deusto 121-154 (2016); Daniel Vaughan-Whitehead (Ed.), The European Social Model in Crisis: Is Europe Losing its Soul? (Edward Elgar 2015); Dagmar Schiek (Ed.): The EU Economic and Social Model in the Global Crisis (Routledge 2013).

${ }^{2}$ Christoph Hermann, 'Crisis, structural reform and the dismantling of the European Social Model(s)', 38(1) Economic and Industrial Democracy 51-68 (2017).
} 
In the sphere of international economic cooperation, the prejudice that politicians should leave the lead to economists, to technicians, has deep roots, above all in the financial world that is a particularly complex biosphere. The discourse that makes the notion of democracy compatible with the technocratic government of certain aspects of community life has been theorized under the concept of 'expert democracy'. ${ }^{3}$ However, in this chapter we take the view that the aseptic separation between technical decisions and political values is impossible in practice. In our perspective, the technical regulation of markets is not objective because any decision supposedly "technical" responds to a political approach and has social consequences (positive and/or negative). In short, any economic rule derives from a prior political approach and responds to a social model.

Today, the main normative decisions for the regulation of European financial markets are taken by the EU. However, when drafting its norms, it often applies standards previously agreed at an international level. Therefore, in order to identify the political choices and the interests embedded in this legislation, we examine the way in which financial regulation is produced in general and the degree in which fairness and maximization of social welfare are taken (or not) into account (section II). Subsequently, we analyze how European financial norms and decisions are made and we pay special attention to the mechanisms of democratic control established in the EU in order to evaluate if this normative output reflects the distributional preferences of the citizenry (section III). After this critical review of financial regulatory processes both at the general and European levels, we study three paradigmatic examples of financial reform (the recovery and resolution of banks, the financial transaction tax and the limits on the remuneration of financial executives) that epitomized a promise made by the public authorities to the population after the 2008 crisis: taxpayers will not have to bear the heavy burden of rescuing failing financial undertakings to avoid the collapse of the capital market in the future, credit institutions and investment firms will have to compensate the social effort made to redress the financial crisis, and executives will not enjoy extra remuneration in spite of having ruined their financial undertaking (section IV). This analysis will allow us to evaluate if the distributional effects of these reforms suffice to talk of a social market economy that is coherent with the core elements of the European social model (section V).

\section{Regulating Financial Markets}

In this section we will explore the special characteristics of the normative production that regulates financial markets. This analysis is applicable at the state,

\footnotetext{
${ }^{3}$ Vibert explains that in today's complex societies it is impossible for the great majority of citizens to have access to the empirical knowledge and the understanding of the information that is needed to make decisions in many fields of governance. When decisions are based on empirical facts and not on political values, safeguarding the independence of the agencies taking such decisions would lead to a better regulatory output. In that context, the legitimacy and quality of the regulatory production of public agencies would be better served through the direct contact with citizens/stakeholders rather than with political interference (Frank Vibert, The Rise of the Unelected (CUP 2007), in particular chapters 6 and 7. See also Cathrine Holst (Ed.), Expertise and Democracy, ARENA Report No 1/14 (2014), available at https://www.sv.uio.no/arena/english/research/publications/arena-reports/2014/report-0114.pdf.
} 
European and international levels, but we will pay particular attention to the international dimension of this regulatory output. This will help us to better understand the framework in which EU financial legislation operates.

\subsection{The technocratic isolation of financial rule-makers}

The regulation of financial markets has traditionally been the preserve of an elite of highly skilled professionals that often crosses the revolving doors between the standard setting bodies and the financial firms, because the inside experience in the financial markets is deemed necessary to perform properly this normative task.

International rules are drafted in standard setting bodies of limited geographical composition ${ }^{4}$ that work with lack of transparency and weak accountability tools. For example, the Financial Stability Board (FSB) which is the main network coordinating international financial institutions, central banks and international (and national) financial regulatory bodies is accountable to the G-20, an informal cooperation body that is not suited for a detailed control of normative activities. The lack of transparency in the FSB's work makes the democratic control of the political choices driving its regulatory output even more difficult. ${ }^{5}$ While large international financial organizations (such as the International Monetary Fund [IMF] or the World Bank) have substantially increased their transparency and their interaction with civil society organizations in recent years, the standard setting bodies coordinated by the FSB (such as the Basle Committee on Banking Supervision or the International Organization of Securities Commissions) continue to perform their regulatory task far from parliamentary debates or the scrutiny of the mass media.

The analysis of this normative output's legitimacy goes beyond the traditional dialectic in international law between the Executives' autonomy in the drafting on international rules and its parliamentary control. In the case of financial standards, highly sophisticated technocrats substitute the politicians as state representatives and there is usually little (if any) change in their positions derived from the evolution of the parliamentary majority in their home country. ${ }^{6}$ Only the biggest players (both the countries with the main capital markets and leading financial firms) in the capital market can exert a real influence in the rule-making result of these international bodies.

\footnotetext{
${ }^{4}$ Some of these institutions have created regional groups to reach out to non-members and widen the geographical scope of their activities (e.g. the FSB established in 2011 six regional consultative groups). However, this move has more to do with their interest in disseminating their standards and adapting them to the circumstances of specific regions than with providing those third countries with a real influence in the standard setting process. De facto, it is often close to technical assistance (see e.g. FSB Regional Consultative Group for Sub-Saharan Africa, Working Group on Home-Host Cooperation and Information Sharing: Initial findings, 26 January 2018 available at http://www.fsb.org/wp-content/uploads/P260118.pdf).

${ }^{5}$ Luis M. Hinojosa-Martínez, 'Transparency in International Financial Institutions', in A. Bianchi/A. Peters, Transparency in International Law (CUP 2013) 106-109.

${ }^{6}$ Camilo Soto Crespo, 'Explaining the Financial Stability Board: Path Dependency and Zealous

Regulatory Apprehension', 5 Penn State Journal of Law \& International Affairs 302-327 (2017) at

324; Chris Brummer, 'How International Financial Law Works', 99 Georgetown Law Journal 257

(2011) at 273-280.
} 
It is true that these standards take the form of non-compulsory codes of conduct, but they receive the political support of the G-20 and the most important financial institutions. In practice, they are usually implemented with minor adaptations by national legislators and thus become the hard law regulating financial markets. This allows us to speak of a worldwide technocratic law regulating global financial markets.

Political parties in democratic countries have not given great relevance to the debate on the regulation of financial markets except perhaps in the worst period of the recent financial crisis and in the countries more punished by its consequences. ${ }^{7}$ The discussion of the kind of safety nets that ought to be established to make banks more resilient or on the appropriate limits to short selling in stock exchanges, for example, are usually absent from parliamentary debates. Most politicians find themselves uncomfortable when engaging in such deliberations and think that those complex technical arguments will not be understood by most of their potential electors (and are therefore worthless). This favors remitting the regulatory tasks to financial 'experts'.

The relevance of self-regulation further reinforces the aseptic normative isolation of the financial world. In the liberal Anglo-Saxon tradition traders and bankers established through contracts and professional societies the normative framework for the development of their business with little intervention from the state. The Central Bank was considered more as the primus inter pares among the merchant banks, with an advisory rather than a disciplinary role and a function of defense of the main capitalists' interests from political interference. ${ }^{8}$ The great Anglo-Saxon influence in the configuration of modern capital markets ${ }^{9}$ helps us to understand the importance of self-regulation in this field, and provides a rationale that justifies leaving the regulation of money markets to their participants and keeping them safe from narrow-minded politicians with short-term interests. ${ }^{10}$ The selfregulation of international financial markets is achieved in two complementary ways: directly by keeping fields of financial activity ruled by private contract, ${ }^{11}$ and indirectly by influencing the (national and international) financial rule-makers with a formidable lobbying capacity (regulatory capture). ${ }^{12}$

\footnotetext{
${ }^{7}$ Nicholas Dorn, 'Financial market regulation: still a regime removed from politics?', in Ismail Etürk/Daniela Gabor (Eds.), The Routledge Companion to Banking Regulation and Reform (Routledge 2016) 290-294.

${ }^{8}$ Nicholas Dorn, Democracy and Diversity in Financial Market Regulation (Routledge 2015) 7-12.

${ }^{9}$ Lucia Quaglia, 'European Union Financial Regulation, Banking Union, Capital Markets Union and the UK', in Colin Hay/Daniel Bailey (Eds.), Diverging Capitalisms. Britain, the City of London and Europe (Palgrave MacMillan 2019) 99-123.

${ }^{10}$ Defending self-regulation to avoid administrative hurdles and promote innovation, see Christodoulos Stefanadis, 'Self-Regulation, Innovation, and the Financial Industry', 23 Journal of Regulatory Economics 5 (2003).

${ }^{11}$ For example, sovereign debt restructuring; see Matthias Goldmann, 'Public and Private Authority in a Global Setting: The Example of Sovereign Debt Restructuring', 25 Ind. J. Global Legal Stud. 331 (2018); IMF, Strengthening the Contractual Framework to Address Collective Action Problems in Sovereign Debt Restructuring, Staff Report (October 2014), available at https://www.imf.org/external/np/pp/eng/2014/090214.pdf.

12 The fact that politicians often feel that it is their duty to support the national financial industry against foreign competitors, and the need to obtain financing for their projects, are often described
} 
Indeed, the financial industry is interested in preventing an open and public debate on the regulation of financial markets that takes into account not only the need to keep the liquidity of markets, stop the contagion effects of failing banks, foster diversification of risks and promote the activities of the national financial champions, but also privileges the protection of consumers' rights and taxpayers' interests. The status quo benefits present financial market operators because gains are private while losses are to a great extent socialized in today's world. The challenge for those purporting a narrative for a more democratic regulation of financial markets is to make it compatible with their efficient functioning so that they can continue providing their very important social function: the financing of productive economy and the facilitation of daily economic transactions of physical and legal persons.

\subsection{The role of the public authorities: Regulation v. Deregulation}

Scholars can be divided depending on whom is identified as the main culprit of the 2008 financial crisis. Some authors blame the markets and identify deregulation, excessive risk-taking and opaqueness of certain financial products as the main causes of the crisis while others accuse weaknesses in regulation (policies encouraging housing ownership, capital regulations, leniency with risky derivative products, or even excessively generous bail-outs/safety nets) as the most relevant triggers of the financial markets' collapse. Most authors, however, would point towards a multi-faceted responsibility including both market and regulatory failures. ${ }^{13}$

It would be inaccurate to identify market insiders (financial firms) as generally favoring deregulation while attributing to market outsiders (those that only use financial markets as end consumers) a preference for stronger regulation. Hart has submitted that in times of crisis both insiders and outsiders similarly increase their support for more regulation; it is in times of growth when there is a greater

as the main causes of 'regulatory capture'. Besides, the regulators need data on the functioning of the markets that only insiders can provide. The studies and analysis that the big financial firms can produce give additional incentives to public authorities to look at financial reform from the perspective of those leading this industry (Anat R. Admati, 'It Takes a Village to Maintain a Dangerous Financial System', in Lisa Herzog (Ed), Just Financial Markets? (OUP 2017) 293-315; Christopher Arup, 'The Global Financial Crisis: Learning from Regulatory and Governance Studies', 32(3) Law \& Policy 363 (2010) at 364-367; Kenneth Haar et al., A Captive Commission: The Role of the Financial Industry in Shaping EU Legislation, October 2009, available at https://www.altereu.org/sites/default/files/documents/a-captive-commission-5-11-09.pdf).

13 Tons of paper have been written discussing the causes of 2008 financial crisis. For this doctrinal debate, see among others John B. Taylor, Government as a Cause of the 2008 Financial Crisis: A Reassessment after 10 Years, Hoover Institution Economics Working Paper 18116 (2018), available at https://www.hoover.org/sites/default/files/research/docs/18116_taylor.pdf; Philip Turner, Did Central Banks Cause the Last Financial Crisis? Will They Cause the Next?, Discussion Paper no 484, 2017, National Institute of Economic and Social Research, available at https://www.niesr.ac.uk/sites/default/files/publications/DP484.pdf; Özgür Orhangazi, Financial deregulation and the 2007-08 US financial crisis, FESSUD Working Paper Series No. 49 (2014), available at http://fessud.eu/wp-content/uploads/2013/04/Financial-deregulation-and-the-200708-US-financial-crisis-Working-Paper-49.pdf; Eilís Ferran/ Niamh Moloney/ Jennifer Hill/ John C. Coffee, The Regulatory Aftermath of the Financial Crisis (CUP 2012); Emilios Avgouleas, Governance of Global Financial Markets (CUP 2012). 
preference for the deregulation by insiders than by outsiders. ${ }^{14}$ When the economy is expanding, the perspective of increased gains makes insiders more easily forget the prudence that generated consensus in times of recession (fewer benefits in exchange for a more stable market). Outsiders do not receive such a strong incentive to change their views in times of economic upswing.

It is the legislator's task to strike a balance and decide on the appropriate quantity of regulation. The extraordinary complexity of today's financial markets rules out civil society giving a detailed mandate to its democratic representatives on the level of regulation for each financial market or product. However, these economic activities should be regulated giving priority to financial stability (a common good that benefits everybody) above extraordinary benefits for the financial industry. Besides, the level of regulation should be compatible with the political preferences expressed by the population in democratic elections. ${ }^{15}$ Thus there is no objective optimal level of regulation, but each jurisdiction will have to define its particularities within the framework established by international coordination.

Except for those that would like to go back to the times of ring-fenced national capital markets, the establishment of international standards is indispensable for an ordered governance of global capital markets, to provide a level playing field for international financial firms and to minimize the spill-over effects of financial crises. From a global perspective, the fact that the international normative framework is established by standard setting bodies that produce non-binding codes of conduct favors a loose regulatory framework based on the minimum common denominator (to reach compromises and foster compliance). ${ }^{16}$ In the case of the European Union, there was wide consensus after the 2008 crisis on the need to strengthen financial integration and to improve and reinforce capital market regulation. We will examine later whether these reforms have lived up to their expectations.

When we refer to the degree of state intervention in financial markets we cannot forget the increasingly important role of central banks not only as regulators but also as providers of liquidity, market operators and lenders of last resort. After the 2008 crisis the social consequences of central banks' policies became undeniable and the old theories that sustained the political neutrality of monetary policy were phased out. ${ }^{17}$ Central banks not only use interest rates to influence the level of inflation and money supply but have recourse to new and unconventional instruments such as quantitative easing and other open market operations (in

\footnotetext{
14 Derek Hart, 'Market Regulation Preferences: Investor Influence? Regulation Preference Paradigms of Financial Markets in the 21st century', 8(1) International Journal of Business and Social Science 133 (2017) 137-139.

15 Dorn (2016) supra n. 7 at 298-300.

${ }^{16}$ Renate Mayntz, 'International Institutions of Financial Market Regulation: An Example of Network Governance?', in Hollstein B., Matiaske W., Schnapp KU. (eds) Networked Governance (Springer 2017) at 82.

17 Peter Dietsch, 'Normative Dimensions of Central Banking: How the Guardians of Financial Markets Affect Justice', in Lisa Herzog (Ed), Just Financial Markets? (OUP 2017) 231; John R. Freeman, 'Competing Commitments: Technocracy and Democracy in the Design of Monetary Institutions', 56 International Organization 889 (2002) at 901-906.
} 
particular, the acquisition of state bonds), 18 that have a direct impact on the public authorities' capacity to finance social policies and entail distributional effects. ${ }^{19}$ The European Central Bank (ECB) has assumed a particularly active role in the context of the measures taken to counter the financial crises and banish the existential threats to the European monetary union. ${ }^{20}$ The recognition of its audacity to sail in troubled waters and to avoid the worst scenarios must run in parallel to the request of enhanced accountability in a way that is proportionate to the political relevance of its decisions. ${ }^{21}$

\subsection{Efficiency and fairness in the reform of financial market regulation}

Any reform of financial markets should have as its ultimate objective the better fulfillment of their social functions: providing the real economy with swift instruments to channel capital from its owners towards investors (efficient allocation of resources), diversifying the risks and facilitating payments. This should be done in the most effective way and with the minimum social and economic cost. The social cost can be measured as the degree of unfairness/inequality generated and the number of people made worse-off by a certain policy or law. The idea that any reform that increases the ethical requirements of financial firms will necessarily prejudice their profits or their resilience should be disregarded as an unfounded prejudice that needs to be verified on a case-by-case basis. ${ }^{22}$ The increase in social peace or in the stability of financial markets may generate benefits that compensate the burdens derived from such reform.

\footnotetext{
${ }^{18}$ In its Gauweiler judgment, the ECJ established that the ECB's program of Outright Monetary Transactions (that involves the purchase of government bonds in secondary markets) is part of the monetary policy and not 'economic policy measures' despite the potential 'indirect' consequences on the economic policy of specific member states. It has later confirmed that the Public Sector Purchasing Program put in place by Decision (EU) 2015/774 of the ECB is also a legitimate and proportionate instrument of monetary policy. See the judgments of the CJEU of 11 December 2018, Weiss and others, Case C-493/17, 55-61 and of 16 June 2015, Gauweiler, Case C-62/14, 55-59 (Andrej Lang, 'Ultra vires review of the ECB's policy of quantitative easing: An analysis of the German Constitutional Court's preliminary reference order in the PSPP case', 55(3) Common Market Law Review, 923-951 (2018); Alicia Hinarejos, 'Gauweiler and the Outright Monetary Transactions Programme: The Mandate of the European Central Bank and the Changing Nature of Economic and Monetary Union', 11 European Constitutional Law Review 563-576 (2015)).

${ }^{19}$ Richard Dobbs et al., QE and ultra-low interest rates: Distributional effects and risks (McKinsey Global Institute 2013), available at https://www.mckinsey.com.

${ }^{20}$ Sebastian Watzka, 'Contagion Risk During the Euro Area Sovereign Debt Crisis: Greece, Convertibility Risk, and the ECB as Lender of Last Resort', in Frank Heinemann/ Ulrich Klüh/ Sebastian Watzka (Eds,), Monetary Policy, Financial Crises, and the Macroeconomy (Springer 2017) 79-104; Tomas Hirst, 'What the ECB is doing to Greek banks is outrageous', Business Insider (2 February 2015) available at https://www.businessinsider.com/ecb-threats-greece-overemergency-funding-2015-2?IR=T.

${ }^{21}$ Grégory Claeys/ Mark Hallerberg/ Olga Tschekassin, European Central Bank accountability: How the monetary dialogue could be improved, Bruegel Policy Contribution, No. 2014/04 available at https://www.econstor.eu/bitstream/10419/106320/1/779994744.pdf.

${ }^{22}$ E.g. Bouslah et al. submit that the increase in the standards of social performance significantly reduces volatility for companies during financial crises (Kais Bouslah/ Lawrence Kryzanowski/ Bouchra M'Zali, 'Social Performance and Firm Risk: Impact of the Financial Crisis', 149(3) Journal of Business Ethics 643 (2018)).
} 
In this context, not every new product that increases the speed at which transactions are finalized (or the number of transactions, or their automation) in the capital markets will necessarily improve their performance. ${ }^{23}$ As happens with energy production, even if coal may be a cheaper way to generate electricity in some circumstances, it is widely acknowledged that its use must be reduced for the social cost (in terms of pollution) that it involves. ${ }^{24}$ Thus, the reduction of the social cost should be taken as one of the elements that can improve the functioning of financial markets, as is the case with the reduction of certain risks that might generate liquidity at first sight but pose an excessive threat to financial stability. ${ }^{25}$

In theory, the price of each financial asset reflects its potentiality to produce income in the future according to the best available information. The market should reward those operators that adapt most quickly to new information or opportunities with the highest profit. But history teaches us that the price of each product in the capital market does not always accurately show its real value. This may be explained by different reasons: poor or asymmetric information, irrational behavior, deficient regulation, market externalities, political interference, etc. ${ }^{26}$ When the state legislates to correct these imperfections it makes the market more efficient is spite of the administrative burdens imposed on its participants. The same happens when capital requirements are established for banks or certain commercial practices are restricted for their negative externalities. ${ }^{27}$

It is no longer possible to encapsulate capital markets as an isolated reality in which the Pareto efficiency principle ${ }^{28}$ is the only parameter of normative reform. ${ }^{29}$ Besides, the Pareto equilibrium cannot be calculated just in terms of per capita income or short term satisfaction of consumer preferences. ${ }^{30}$ The objectives

\footnotetext{
${ }^{23}$ Songzi Du/ Haoxiang Zhu, 'What is the Optimal Trading Frequency in Financial Markets?', 84(4) The Review of Economic Studies 1606-1651 (2017); Tim Harford, 'High-frequency trading and the \$440m mistake', (11 August 2012) available at https://www.bbc.com/news/magazine-19214294. ${ }^{24}$ David Anthoff/ Johannes Emmerling, 'Inequality and the Social Cost of Carbon', 6(2) Journal of the Association of Environmental and Resource Economists 29 (2019).

${ }^{25}$ Michael R. King/ Philipp Maier, 'Hedge funds and financial stability: Regulating prime brokers will mitigate systemic risks' 5(3) Journal of Financial Stability 283-297 (2009).

${ }^{26} \mathrm{~A}$ line of thinking compares the behavior of capital markets to a casino (Susan Strange, Casino Capitalism (Manchester University Press 2015); Hans-Werner Sinn, Casino Capitalism. How the Financial Crisis Came About and What Needs to be Done Now (OUP 2012)). Other authors present these inefficiencies as market imperfections that do not question their general capacity to provide an efficient allocation of resources in spite of the costly distortions that they generate (Tarek A. Hassan/ Thomas M. Mertens, 'The Social Cost of Near-Rational Investment' 107(4) American Economic Review 1059-1103 (2017)).

${ }^{27}$ Adam C. Kolasinski/ Adam Reed/ Jacob R. Thornock, 'Can Short Restrictions Actually Increase Informed Short Selling?' 42(1) Financial Management 155-181 (2013).

${ }^{28}$ The Pareto efficiency principle aims at a situation of perfect competition in which resources are allocated in the best way possible because no additional trade can make anyone better off without making other individual(s) worse off. From a legal point of view, when the legislative framework favors this ideal situation, we speak of the Pareto equilibrium.

${ }^{29}$ For a defense of the advantages of a social methodology for the analysis of financial markets' performance and regulation with the instruments of behavioral economics see Julia Black, Seeing, Knowing, and Regulating Financial Markets: Moving the Cognitive Framework from the Economic to the Social, LSE Law, Society and Economy Working Papers 24/2013, available at https://papers.ssrn.com/sol3/papers.cfm?abstract_id=2346098.

${ }^{30}$ On the relationship between Pareto efficient behavior and ethic management of firms, see Jeffery Smith, 'Efficiency and Ethically Responsible Management', 150(3) Journal of Business Ethics 603-
} 
of the norm should also include the achievement of the minimum elements of justice and equality that society requests. It is this complex mix of objectives that should provide the criteria to evaluate the maximization of social welfare to be attained by the norm. ${ }^{31}$

Financial markets undoubtedly have a strong impact on the distribution of wealth and opportunities, on the bargaining power of labor vis-à-vis capital ${ }^{32}$ and therefore on the social model. Their reform should involve a previous evaluation of their social cost as part of the analysis on the most efficient way in which they can fulfill their general functions. ${ }^{33}$

I agree with Claassen's submission in the sense that any financial reform must take into account the interests of three groups of stakeholders: market participants (banks and other financial firms), consumers (persons that only participate in the financial market as end consumers) and third parties affected (those that do not participate in the financial market as producers or consumers but whose interests are touched by its externalities, namely taxpayers or workers of the productive industries). ${ }^{34}$ During the period of liberalization of capital markets since the mid eighties to 2007, financial regulation prioritized the provision of liquidity and the globalization of money markets, and as corollary the growth of financial markets and of employment and remuneration in that profession. ${ }^{35}$ In other words, financial regulation favored the interests of market participants above those of consumers and third parties.

618 (2018). Criticizing the preference for the utilitarian approach in the configuration of markets, see Shengwu Li, 'Ethics and Market Design', 33(4) Oxford Review of Economic Policy 705-720 (2017).

${ }^{31}$ We are using here the epistemological instruments of the normative economy that defends the critical analysis of law from the perspective of its efficacy to achieve its objectives that must be evaluated as an instrument of social welfare maximization (Luis M. Hinojosa-Martínez, "A favor del análisis económico del Derecho internacional y de la renovación metodológica", en Anna M. Badia (Coord.), El Derecho internacional ante los retos de nuestro tiempo. Homenaje a la Profesora Victoria Abellán Honrubia (Marcial Pons 2009) 415-417; Bingyuan Hsiung, 'Economic Analysis of Law: an Inquary in its Underlying Logic', 2(1) Erasmus Law and Economics Review 1 (2006) at 15-16).

32 For an analysis of the influence in the labor market of the financialization of the economy see Thibault Darcillon, 'Labor-Market Volatility and Financial Development in the Advanced OECD Countries: Does Labor-Market Regulation Matter?', 58 Comparative Economic Studies 254-278 (2016); John Grahl, 'Financial Change and European Employment Relations', en John Grahl (Ed.), Global Finance and Social Europe (Edward Elgar 2009) 123.

33 While some authors establish a clear dichotomy between the markets (that should be ruled by efficiency) and the state (that provides justice and corrects social inequalities through redistributive policies), in this paper we submit that the social cost of injustice and unfairness is a very relevant factor to evaluate market efficiency (Irene van Staveren, 'The ethics of efficiency', SCEME Working Papers: Advances in Economic Methodology 018/2007 available at https://ideas.repec.org/p/sti/wpaper/018-2007.html; Samuel Bowles/Herbert Gintis, 'Efficient Redistribution: New Rules for Markets, States and Communities', 24 Politics and Society 307 (1996)).

34 Rutger Claassen, 'A capability Framework for Financial Market Regulation' in Lisa Herzog (Ed), Just Financial Markets? (OUP 2017) 56-77.

${ }^{35}$ Lisa Herzog, 'Can Incomes in Financial Markets be Deserved? A Justice-Based Critique', in Lisa Herzog (Ed), Just Financial Markets? (OUP 2017) 103-121; Lutz G. Arnold/ Sebastian Zelzner, The Allocation of Talent to Financial Trading versus Entrepreneurship: Welfare Effects of Trading in General Equilibrium (2016) available at https://www.vwl.unimannheim.de/media/Lehrstuehle/vwl/DFG_1578/Publications/Arnold_Zelzner_2018.pdf. 
The severity and depth of the 2008 financial crisis has brought to light this imbalance. In the first place, consumers clearly needed more protection to shelter them from the abuses of an industry that offered extremely complex products that were incomprehensible for the average citizen and sometimes misleading for the average investor. ${ }^{36}$ But in the second place, the most relevant lesson of this crisis has been that negative externalities for third parties had not been adequately taken into account in economic theory and many of them cannot be tolerated. ${ }^{37}$ The losses generated for society were clearly underestimated in previous studies on the efficiency and functioning of financial markets ${ }^{38}$ and their profound reform became a priority political demand. Unfortunately, the political thrust that propelled such reform from 2008-2009 has weakened today and many of the hopes it raised have been frustrated to a great extent.

\section{The governance of European Financial Markets}

This section reviews how the EU's financial normative output is produced and the way in which it reflects the general trends described in the previous section. We want to determine if the EU's regulatory competences and procedures enable it to build a social market economy in which financial markets can be regulated with appropriate mechanisms of accountability and democratic control.

\subsection{The EU's normative framework}

A doctrinal sector has often accused the European integration process of fostering economic liberalization as an instrument to achieve market integration or even an enhanced political union. According to this discourse, the consolidation of panEuropean markets would have been privileged over the protection of the European social model, and negative normative techniques (the prohibition of restrictions) would have favored de facto market deregulation. ${ }^{39}$ This alleged trend would also apply to the financial markets in a process that began in the eighties with the liberalization of capital movements (first between member states and afterwards also with third countries), was complemented with the elimination of the obstacles to the transnational provision of financial services and reinforced with the

\footnotetext{
${ }^{36}$ Manuel B. Aalbers/ Jannes Van Loon/ Rodrigo Fernandez, 'The Financialization of A Social Housing Provider' 41(4) International Journal of Urban and Regional Research 572-587 (2017); Neil Fligstein/ Alexander F. Roehrkasse, 'The Causes of Fraud in the Financial Crisis of 2007 to 2009: Evidence from the Mortgage-Backed Securities Industry' 81(4) American Sociological Review 617643 (2016).

${ }^{37}$ Russ Roberts, Gambling with Other People's Money. How Perverse Incentives Caused the Financial Crisis (Hoover Institution Press 2019); Ioannis N. Kallianiotis, 'Privatization in Greece and Its Negative Effects on the Nation's Social Welfare (Expropriation of the National Wealth)' 19(1) Journal of Business \& Economic Studies 1-23 (2013).

${ }^{38}$ Ben Bernanke, The Real Effects of Disrupted Credit Evidence from the Global Financial Crisis, Brookings Papers on Economic Activity (13-14 September 2018), available at http://tankona.free.fr/bernanke918.pdf.

${ }^{39}$ For this debate, see Jason Beckfield, Unequal Europe: Regional Integration and the Rise of European Inequality (OUP 2019); Marija Bartl, 'Internal market rationality: In the way of reimagining the future', 24(1) European Law Journal 99-115 (2018); Betina Leibetseder, 'Social investment policies and the European Union: Swimming against the neoliberal tide?', 16(4) Comparative European Politics 581-601 (2018).
} 
consolidation of the European economic and monetary union. The initiatives to create a Capital Markets Union ${ }^{40}$ and the still incomplete Banking Union ${ }^{41}$ are two additional steps in the construction of a fully integrated financial market in the EU.

However, the EU's economic constitutional framework is explicitly compatible with social markets. From the formal proclamation of the fundamental principles (Article 3 EU Treaty says that the EU shall establish a 'social market economy') ${ }^{42}$ to the positive techniques of economic integration through harmonization (e.g. Articles 49, 56, 63, 114 and 352 TFEU in the context of finance), the legislative tools for the regulation of European markets are prepared to be compatible with different political ideologies and a social conception of the market. ${ }^{43}$ The case law of the CJEU has been generally respectful of member states' social protection rules $^{44}$ in spite of some controversial decisions on labor standards ${ }^{45}$ and its general support for the extraordinary measures taken to avoid the destruction of the Eurozone during the crisis (even if they had harmful consequences for individuals). ${ }^{46}$ In any case, the responsibility for the legislation enacted for the regulation of European financial markets should be attributed to the majorities

${ }^{40}$ Communication from the Commission 'Action Plan on Building a Capital Markets Union', Doc. $\operatorname{COM}(2015) 468$ final, 30 September 2015, and the mid-term review in Doc. COM(2017) 292 final, 8 June 2017.

${ }^{41}$ Communication from the Commission 'A Roadmap towards a Banking Union', Doc. COM (2012) 510 final, 19 September 2012, and 'on completing the Banking Union' COM (2017) 592 final, 11 October 2017.

${ }^{42}$ This has to be complemented with Articles 34 to 38 of the Charter of Fundamental Rights of the EU that protect several social rights and Articles 151 to 164 TFEU (EU social policy and European Social Fund). See Delia Ferri/ Fulvio Cortese (Eds.), The EU Social Market Economy and the Law. Theoretical Perspectives and Practical Challenges for the EU (Routledge 2019); Linxin He, 'Les droits sociaux fondamentaux et le droit de l'Union européenne', 54(1) Revue trimestrielle de droit européen 25-44 (2018); Graham Butler, 'Solidarity and its Limits for Economic Integration in the European Union's Internal Market', 25(3) Maastricht Journal of European and Comparative Law 310-331 (2018); Ainhoa Lasa López, `Constitución económica europea y modelo social: límites e ineficiencias de la integración negative mejorada en la lucha contra la exclusion social' 53 Cuadernos Europeos de Deusto 133-165 (2015).

${ }^{43}$ Dragana Damjanovic, "The EU Market Rules as Social Market Rules: Why the EU can be a Social Market Economy', 50 C.M.LRev. 1685-1718 (2013).

${ }^{44}$ Overriding principles of general interest may justify a restriction to the internal market freedoms if it respects the principle of proportionality. In the context of the provision of financial services, see for example the judgments of the CJEU of 14 February 2019, Milivojevic, C-630/17, 71-72, and of 10 May 1995, Alpine Investments, C-384/93, 44. In relation to the protection of the member states' social system, see among others the judgments of 21 June 2012, Susisalo et al., C-84/11, 31-44 (health system), and of 21 September 1999, Albany, C-67/96, 111 (pension funds). However, criticizing the lack of 'sensitivity' of the Court for using a 'harsh' proportionality test in this context see Sionaidh Douglas-Scott/ Nicholas Hatzis, 'EU Law and Social Rights', in Sionaidh Douglas-Scott/ Nicholas Hatzis (Eds.), Research Handbook on EU Law and Human Rights (Edward Elgar 2017) 492515 at 509.

${ }^{45}$ E.g., Judgments of the CJEU of 3 April 2008, Rüffert, C-346/06, of 11 December 2007, Vicking, C438/05, and of 18 December 2007, Laval, C-341/05 (Mark R. Freedland, Jeremias Prassl (Eds.), Viking, Laval and Beyond (Hart 2016)).

${ }^{46}$ E.g., judgments of the CJEU of 13 June 2017, Florescu, C-258/14, and of of 20 September 2016, Mallis et al., C-105/15 to C-109/15 (Menelaos Markakis/ Paul Dermine, 'Bailouts, the Legal Status of Memoranda of Understanding, and the Scope of Application of the EU Charter: Florescu', 55(2) Common Market Law Review 643-671 (2018)). 
existing in the European legislative bodies at that time ${ }^{47}$ rather than to an indelible original sin of the integration process. The articulation of more or less generous social policies continues to be a competence essentially in the hands of the member states, perhaps with the exception of the very unusual period of the recent financial crisis for those member states subject to rescue packages whose budgetary sovereignty has been significantly eroded..$^{48}$

\subsection{Lamfalussy, de Larosière and Agencification}

The technical complexity of the financial markets and their great capacity of innovation and transformation made it difficult to use the European ordinary legislative procedure to regulate and harmonize them adequately in order to foster the articulation of a pan-European capital market. At the beginning of the twentyfirst century financial companies still suffered significant hurdles in their transnational activities and the EU decided to improve its regulatory capacity in this field through what was known as the Lamfalussy process. The European Commission launched a Financial Services Action Plan in 1999 with the objective of 'establishing a single market in wholesale financial services, making retail markets open and secure and strengthening the rules on prudential supervision'. ${ }^{4}$ In the course of that process, the European Council adopted the 'Final Report of the Committee of Wise Men on the Regulation of European Securities Markets' (headed by Alexandre Lamfalussy) on 23 March 2001.50 This document established the framework for the subsequent reform in the regulation of European financial markets. It distinguished four levels of European action:

Level 1. The ordinary legislative procedure (Regulations and Directives approved by the European Parliament and the Council at the proposal of the Commission) in which consultation with market operators would be enhanced.

Level 2. To avoid the slow process of level 1, the Commission would adopt and update the rules implementing the legislation passed at level 1 following a revised

\footnotetext{
${ }^{47}$ Floris de Witte has criticized the evolution in the priorities of EU social policy in The Architecture of a 'Social Market Economy', LSE Legal Working Paper No. 13/2015, available at SSRN.

${ }^{48}$ See the different contributions in Caroline De La Porte/ Elke Heins (Eds.), The Sovereign Debt Crisis, the EU and Welfare State Reform (Palgrave 2016); Anton Hemerijck, The Euro-Crisis Welfare State Conumdrum', in Maria J. Rodrigues/ Eleni Xiarchogiannopoulou (Eds.), The Eurozone Crisis and the Transformation of EU Governance (Ashgate 2014) 137-156. Nevertheless, all the member states in the Eurozone accept constraints in their budgetary sovereignty (José Ma Porras Ramírez, 'Intergubernamentalismo y tecnocracia en la gobernanza económica de la Unión Europea. El cuestionado papel de las instituciones dotadas de poderes ejecutivos', in Francisco J. Carrera Hernández (Coord.), ¿Hacia una nueva gobernanza económica de la Unión Europea? (Aranzadi 2018) 113-144; Olivier Clerc, 'Le conditionnement des budgets locaux par les règles européennes de gouvernance économique : l'exemple italien', 626 Revue du marché commun et de l'Union Européenne 163-169 (2019)).

${ }^{49}$ Commission Communication of 11 May 1999 [COM(1999) 232 final].

50 The Report is available at https://www.esma.europa.eu/document/lamfalussy-report. For a comment see Christian De Visscher/ Olivier Maiscocq/ Frédéric Varone, 'The Lamfalussy Reform in the EU Securities Markets: Fiduciary Relationships, Policy Effectiveness and Balance of Power', 28(1) Journal of Public Policy 19-47 (2008); Duncan Alford, 'The Lamfalussy Process and EU Bank Regulation: Another Step on the Road to Pan-European Regulation?', 25 Annual Review of Banking \& Finance Law 389 (2006).
} 
comitology procedure. ${ }^{51}$ The lower participation of the Council and the European Parliament at this level favors a quicker and more flexible decision-making.

Level 3. Committees of national supervisors (composed of the national supervisory authorities and different from the level 2 committees where member states' governments were directly represented) were created to issue recommendations and to harmonize the interpretation of the binding rules in their task of supervision. Although level 3 guidelines should be considered soft-law, the peer review system that they established and their precision considerably increased the harmonization of supervisory standards in the EU and the level of complexity of the European normative output. 52

Level 4. The Commission should reinforce the vigilance of the correct application of European financial norms (levels 1 and 2) by the member states.

The Lamfalussy process was implemented in the securities field in the first place and formally extended in 2004 to banking, insurance, occupational pensions and asset management although with some variations depending on the financial sector. In general terms, this reform improved the quality and transparency of EU's financial legislation and fostered the integration of European capital markets. ${ }^{53}$

After the outbreak of the 2008 financial crisis, the Commission asked Jacques de Larosière to create a group of experts (High-Level Group on Supervision) that could report on the causes of the crisis, its policy and regulatory repair, the way to improve EU's supervisory performance and the best options for global repair. Building on the diagnosis and recommendations of this Report, ${ }^{54}$ two main institutional reforms were adopted: the creation of a European Systemic Risk Board (ESRB) (to monitor potential risks for financial stability and establish an early warning system $)^{55}$ and the upgrading and transformation of the previous supervisory bodies of level 3 into a European System of Financial Supervisors (ESFS) that included a European Banking Authority (EBA), a European Insurance and Occupational Pensions Authority (EIOPA), and a European Securities Authority (ESA). ${ }^{56}$ In the new scenario created by the entry into force of the Lisbon Treaty (2009) the main reforms in the normative structure affected levels 2 and 3 :

\footnotetext{
${ }^{51}$ Council Decision 1999/468/EC of 28 June 1999 laying down the procedures for the exercise of implementing powers conferred on the Commission (OJ L 184, 17.7.1999, p. 23-26). This act was substituted later by Regulation (EU) No 182/2011 of the European Parliament and of the Council of 16 February 2011 laying down the rules and general principles concerning mechanisms for control by Member States of the Commission's exercise of implementing powers (OJ L 55, 28.2.2011, p. 1318).

52 The margin of interpretation left to the member states by legislation enacted at levels 1 and 2 was significantly reduced in practice by the technical standards produced at level 3.

${ }^{53}$ Zdenek Kudrna, The EU Financial Market Policy: Evolution, Innovation and Research Outlook, OAW Working Paper Series No. 04/2009 (August 2009) 19-22.

${ }^{54}$ The report is available at

https://www.esrb.europa.eu/shared/pdf/de larosiere report en.pdf?351e1b35ec1ca5e855d2e46 5383a311f. See Despina Chatzimanoli, 'A Crisis of Governance? — From Lamfalussy to de Larosière or Bridging the Gap between Law and New Governance in the EU Financial Services Sector', 2(3) European Journal of Risk Regulation 322-339 (2011).

55 Regulation (EU) No 1092/2010 of the European Parliament and of the Council of 24 November 2010 on European Union macro-prudential oversight of the financial system and establishing a European Systemic Risk Board (OJ L 331, 15 December 2010, p. 1).

${ }^{56}$ Regulation (EU) No 1093/2010 of the European Parliament and of the Council of 24 November 2010 establishing a European Supervisory Authority (European Banking Authority); Regulation
} 
Level 2. When level 1 legislation provides for the adoption of level 2 acts it must distinguish between delegated acts (Article 290 TFEU) if the implementing norm is to supplement or amend non-essential elements of the enabling legislative act, and implementing acts (Article 291 TFEU) where uniform conditions for implementing legally binding Union acts are needed.

Level 3. The new European Supervisory Authorities (ESA) could participate in the adoption of binding technical standards in two different ways (to be determined in the enabling legislative act): acts adopted by the Commission through a delegated act in the context of Article 290 TFEU (regulatory technical standards), or implementing acts as envisaged in Article 291(2) TFEU (implementing technical standards). ${ }^{57}$ Before their adoption, the technical standards are systematically subject to public consultation. Thus, the ESA were thereby involved in the elaboration of level 2 measures (binding technical standards). Nevertheless, in the case of the regulatory technical standards, the European Parliament or the Council may revoke the normative delegation at any time (Article 12 of the ESA Regulations) ${ }^{58}$ and regain full control of the normative process. These are the two institutions to which ESA are accountable. The CJEU has established that their control of the normative process is sufficient to safeguard basic democratic legitimacy concerns and coherence with the distribution of powers established in the constituent Treaties. ${ }^{59}$ While some authors would praise the independence of these agencies as a guarantee to preserve the technical quality of their normative

(EU) No 1094/2010 of the European Parliament and of the Council of 24 November 2010 establishing a European Supervisory Authority (European Insurance and Occupational Pensions Authority); Regulation (EU) No 1095/2010 of the European Parliament and of the Council of 24 November 2010 establishing a European Supervisory Authority (European Securities and Markets Authority) (OJ L 331, 15 December 2010, pages 12, 48 and 84). See Fabrice Demarigny/ Jonathan McMahon/ Nicolas Robert, Review of the New European System of Financial Supervision (ESFS). Part 1: The Work of the European Supervisory Authorities (EBA, EIOPA and ESMA) -The ESFS'S Micro-Prudential Pillar, Doc. IP/A/ECON/ST/2012-23, October 2013, European Parliament.

57 Within 3 months of receipt of a draft regulatory technical standard or a draft implementing technical standard, the Commission shall decide whether to endorse it. If the Commission decides not to endorse a draft proposal or to introduce amendments, it has to explain its reasons to the Authority.

${ }^{58}$ In addition, if either the European Parliament or the Council objects to a regulatory technical standard, it shall not enter into force (Article 13 ESA Regulations).

${ }^{59}$ According to the Meroni doctrine (judgment of 13 June 1958, Meroni v. High Authority, Case 9/56, 135), the lawful delegation of powers to independent European agencies by the European institutions is conditioned to a precise delimitation of the powers conferred, an efficient mechanism of control by the delegating institution, the possibility of judicial review, and the absence of transfer of political responsibility. However, more recent case-law distinguishes between 'European Union entit[ies], created by the EU legislature' and private entities (as was the case in Meroni). If we take into account that all the binding decisions of these EU entities are now subject to judicial control (Article 263 TFEU), in a situation where highly technical factual assessments are necessary, and where the factors to take into account to make the decisions and the kind of measures to be adopted are precisely delineated in the delegating act, the requirements laid down in Meroni are to be considered as respected (Judgment of the CJEU of 22 January 2014, United Kingdom v. Council and European Parliament, C-270/12, 41-53). See also Maurizia De Bellis, Procedural Rule-Making of European Supervisory Agencies (ESAs): An Effective Tool for Legitimacy?, TARN Working Paper Series, 12/2017, August 2017 available at SSRN; Fabian Walla, 'Process and Strategies of Capital Market Regulation in Europe', in Rüdiger Veil (Ed.), European Capital Markets Law (Hart 2017) 4653. 
production, others would value this independence negatively as buttressing the traditional democratic deficit in the regulation of financial markets. ${ }^{60}$

The de Larosière reform has thus resulted in a reinforcement of the normative capacity of the European agencies ${ }^{61}$ (in particular in the field of supervision), but also in the assumption of new executive competences ${ }^{62}$ by these bodies with the objective of harmonizing in practice and improving the public authorities input in the European financial markets. ${ }^{63}$ This transfer of competences to the European level of governance increases the influence of the European bodies in the financial conditioning of the social model. Two main instruments try to channel the democratic control of this normative production:

a) A system of broad consultations with interested stakeholders. Articles 10 and 15 of ESA Regulations oblige these agencies (or the Commission, as the case may be) to conduct open public consultations before approving their technical standards. ${ }^{64}$ Even the guidelines and recommendations of these authorities are generally subject to open public consultations (Article 16 ESA Regulations). Each ESA hosts a Stakeholder Group that provides technical advice and comments on its different normative or policy initiatives. ${ }^{65}$ However, in spite of this transparency effort, the consultation procedure is dominated by the big financial corporations that possess the human resources, the information, the interest and the experience to make the

60 Päivi Leino, 'Accountability Dilemmas of Regulating Financial Markets through the European Supervisory Agencies', in Carol Harlow/ Päivi Leino/ Giacinto della Cananea (Eds.), Research Handbook on EU Administrative Law (Edward Elgar 2017) 209-237; Mads Andenas/ Iris H.-Y. Chiu, The Foundations and Future of Financial Regulation. Governance for Responsibility (Routledge 2014) 447-455. However, pointing at the excessive influence of European institutions and member states in the Authorities and defending a higher degree of independence for them, see Matteo Ortino, 'The Case for Truly Independent EU Regulatory Authorities in the Field of Financial Regulation', 29(3) European Business Law Review 465-496 (2018); Ivana Bajakic/ Marta Bozina Veros, 'Examining Agency Governance in the European Union Financial Sector - A Case-Study of the European Securities and Markets Authority' 30(1) Journal of Economic Research-Ekonomska Istraživanja 1743-1757 (2017).

${ }^{61}$ Madalina Busuioc, 'Rule-Making by the European Financial Supervisory Authorities: Walking a Tight Rope' 19(1) European Law Journal 111-125 (2013).

62 ESA can settle disagreements between different national or sectoral competent authorities in cross-border situations, and adopt binding decisions addressed to individual financial companies where a national competent authority does not comply with the decision of the European Authority in relation to that firm (Articles 19 and 20 ESA Regulations). In emergency situations, ESA can also adopt decisions requiring competent authorities to take necessary actions in accordance with the European legislation, although the Council remains the competent institution to declare the existence of such an emergency situation (Article 18 ESA Regulations). These competences cannot interfere with the fiscal responsibilities of member states (Article 38 ESA Regulations). The Commission has proposed to reinforce and increase these competences in the reform of ESA Regulations currently under discussion (Doc. COM(2017) 536 final, 29 September 2017).

63 Kudrna points to several advantages of the normative empowerment of ESA: more effective redistribution of negotiation burdens, growing expert backing of regulation, better balancing of disparate interests, and higher degree in transparency in decision-making (Zdenek Kudrna, 'Governing the EU financial markets', 14(1) Comparative European Politics 71-88 (2016) 80-81).

64 Unless such consultations and analyses are disproportionate in relation to the scope and impact of the draft technical standards concerned or in relation to the particular urgency of the matter. See also Article 15 TFEU.

65 The stakeholder groups contain a balanced representation of providers of financial services, consumers, users and academics. See e.g. https://www.esma.europa.eu/aboutesma/governance/smsg. 
most substantial contributions. 66 The revolving doors between the financial industry and the administrations from which ESA's members originate also favor the climate of understanding between the rule-makers and financial corporations. ${ }^{67}$ In this context, the articulation of stringent rules preventing conflicts of interest inside ESA $^{68}$ is indispensable and yet insufficient to compensate for the big financial firms' de facto power of guidance.

b) The control of political institutions. First, ESA have significantly eroded the Commission's power of initiative, but they cannot disregard the Commission's views because they need its approval for the adoption of their regulatory proposals. ${ }^{69}$ Second, the delegation to adopt regulatory technical standards may be revoked at any time by the Council or the European Parliament (Article 12 ESA Regulations). ${ }^{70}$ Third, the delegation to adopt regulatory technical standards is reevaluated every four years and the Parliament or the Council may decide to revoke it if they are not happy with the general outcome (Article 11 ESA Regulations). These two institutions also adopt ESA's budget (Article 63 ESA Regulations). From my perspective it is not possible to separate the technical judgments of ESA from the political choices that they imply. ${ }^{71}$ The swift governance of financial markets improves with this highly qualified decisionmaking, but the political control ex-post facto of the European Parliament and the Council, together with their indirect instruments of control (such as the assignment of budgetary priorities, or the establishment of political indications), must be placed as an essential element of this procedure if we want citizens to have some influence in the distributional effects of financial market regulation.

${ }^{66}$ Corporate Europe Observatory, How the Financial Lobby Won the Battle in Brussels (13 September 2018), available at https://corporateeurope.org/financial-lobby/2018/09/howfinancial-lobby-won-battle-brussels; Kudrna (2016) supra n. 63 at 82-84.

${ }^{67}$ Duncan Lindo, Still Going Round in Circles: The Revolving Door Between Banks And Their Regulators, Finance Watch (22 February 2019) available at https://www.finance-watch.org/stillgoing-round-in-circles-the-revolving-door-between-banks-and-their-regulators.

${ }^{68}$ E.g. Decision of the Management Board on the EBA's Policy on Independence and Decision Making Processes for avoiding Conflicts of Interest (Conflict of Interest Policy) for Non-Staff (29 September 2014), EBA DC 103, available at https://eba.europa.eu/documents/10180/15718.

${ }^{69}$ According to Articles 10 and 15 of ESA Regulations, the Commission has to endorse ESA's technical standards so that they are published in the OJ and can enter into force. The Commission may not change the content of a draft technical standard prepared by the Authority without prior coordination with the Authority, and it can only adopt the technical standard without a draft from the Authority or modify the text submitted by the Authority by following the procedure of several steps envisaged in the above-mentioned provisions. In any case, the practice has shown the leading role of ESA in this normative production (Marta Simoncini, Administrative Regulation Beyond the Non-Delegation Doctrine A Study on EU Agencies (Hart 2018) 66-88).

${ }^{70}$ This veto power is very rarely used. See the general and comprehensive study of Michael Kaeding, 'Out of Balance? Practical Experience in the European Union with Quasi-Legislative Acts', in Olivier Costa (Ed.), The European Parliament in Times of EU Crisis. Dynamics and Transformations (Palgrave 2018) 161-175.

${ }^{71}$ Simoncini places the regulatory capacity of European agencies within the boundaries of administrative discretion beyond the dichotomy between political and technical powers (Simoncini, supra n. 69 at 89-131). Distinguishing 'content-independent reasons' based on facts in the context of a given mandate from moral/political judgments when evaluating the kind of decisions taken by public agencies, see Andreas Eriksen, Legitimate Agency Reasoning, ARENA Working Paper 1/2018 (April 2018), available at https://www.sv.uio.no/arena/english/research/publications/arena-working-papers/2018/wp-118.pdf. 
Finally, as has already been said, the internationalization of the decision-making process for the regulation of capital markets provides a further element of alienation of the democratic control of European financial norms. This regulatory externalization comes about in two ways:

1) The international normative framework that conditions the European regulatory output. The elitist and technocratic origin of these international rules has already been commented on in this chapter. ${ }^{72}$ Therefore, when the European institutions implement these standards they reproduce the social model embedded in these international rules.

2) The creation of international bodies outside the EU institutional structure to provide stability to European financial markets (European Stability Mechanism, Single Resolution Fund). The economic importance of these entities runs parallel to their distancing from the mechanisms of legitimization and accountability developed in the EU system of multilevel governance. ${ }^{73}$ While the urgencies of the crisis might justify the use of flexible instruments that could be put in place quickly, the long-term management of these important bodies requires the articulation of the appropriate mechanisms of democratic control.

\subsection{The role of the European Central Bank}

This European regulatory framework has to be completed with a reference to the legislative and executive competences of the European Central Bank (ECB) that today not only cover its monetary policy but it also extend to the supervision of credit institutions under the Single Supervisory Mechanism (SSM). ${ }^{74}$ Its powerful normative capacity enables the ECB to make Regulations, Decisions, Recommendations and Opinions (Article 132 TFUE). It can also adopt Guidelines and Instructions to ensure the proper functioning of the European System of Central Banks (Articles 12 and 14 ECB Statute). The ECB can also impose fines or periodic penalty payments on private undertakings for failure to comply with the obligations that it imposes (Article 34(1) ECB Statute). ${ }^{75}$

As a European institution, the conceptual and legal framing of ECB's normative and executive powers is different from that of ESA. The debate on the autonomy of monetary policy and the most adequate mechanisms for its democratic control and the accountability of the Central Bank goes beyond the boundaries of the EU and

\footnotetext{
72 See section 2.1 supra.

73 Sergio Fabbrini, 'From Consensus to Domination: the Intergovernmental Union in a Crisis Situation', 38(5) Journal of European Integration 587-599 (2016).

${ }^{74}$ Council Regulation (EU) No 1024/2013 of 15 October 2013 conferring specific tasks on the European Central Bank concerning policies relating to the prudential supervision of credit institutions (OJ L 287, 29.10.2013, p. 63-89). See Luis M. Hinojosa Martínez, 'The Role of the ECB in the Supervision of Credit Institutions', en L. M. Hinojosa Martínez/J. Ma Beneyto (Eds.), European Banking Union: The New Regime (Kluwer Law International 2015) 47-68.

${ }^{75}$ Regulation (EC) No 2157/1999 of the ECB of 23 September 1999 on the powers of the ECB to impose sanctions (ECB/1999/4), OJ L 264, 12 October 1999, p. 21.
} 
constitutes a classic debate in economic and political literature. ${ }^{76}$ For the purposes of this chapter, it may suffice to note that the constituent Treaties accord great importance to ECB's independence in the design of its monetary policy, ${ }^{77}$ which is subject to a deliberative accountability ${ }^{78}$ but well protected from direct interference from the political institutions. The ECB's reporting obligations allow it to know what it has done and why ex post facto. ${ }^{79}$ In any case, as the other European institutions, the ECB is subject to the control of legality exercised by the CJEU.80

Insofar as the ECB's decisions are made in the inter-governmental institutions (such as the European Stability Mechanism) created during the financial crisis, the same accountability rules apply. ${ }^{81}$ While the legal debate on the compatibility of ECB's activities in these international bodies with its conferred powers has now been clarified by the CJEU, ${ }^{82}$ the opportuneness to increase ECB's accountability for the political decisions taken in the implementation of these new tasks is pressing. ${ }^{83}$

${ }^{76}$ Paul Tucker, Unelected Power: The Quest for Legitimacy in Central Banking and the Regulatory State (Princeton University Press 2018).

77 Neither the ECB nor any of its members 'shall seek or take instructions from Union institutions, bodies, offices or agencies, from any government of a Member State or from any other body'; in addition, the 'Union institutions (...) and the governments of the Member States undertake (...) not to seek to influence the members of the decision-making bodies of the European Central Bank' (Article 130 TFEU). See Stefania Baroncelli, 'The Gauweiler Judgment in View of the Case Law of the European Court of Justice on European Central Bank Independence', 23 Maastricht Journal of European \& Comparative Law 79-98 (2016).

${ }^{78}$ The President of the Council and a Member of the Commission may participate in meetings of the Governing Council of the ECB. The President of the ECB is invited to participate in Council meetings when the Council is discussing matters of ECB's competence. More relevantly, the ECB presents an annual report on its activities to the other European institutions and its President holds a general debate on that basis in the European Parliament. The ECB President and the other members of its Executive Board may, at the request of the European Parliament or on their own initiative, be heard by the competent committees of the European Parliament (Article 284 TFEU).

${ }^{79}$ Besides the already mentioned annual report on its activities, the ECB draws up and publish quarterly reports of activities, consolidated financial statements weekly, and its annual accounts every financial year. These reports are made available to interested parties free of charge (Article 15 ECB Statute). However, the ECB is not obliged to disclose all the documents that it has used or requested in its decision-making in order to safeguard its independence and the confidentiality of its internal deliberations (judgment of the General Court of 12 March 2019, De Masi, T-798/17, 6667). See also Pieter van Cleynenbreugel, 'Confidentiality behind Transparent Doors: The European Central Bank and the EU Law Principle of Openness', 25(1) Maastricht Journal of European and Comparative Law 52-76 (2018).

80 Jacopo Alberti, 'Challenging the Evolution of EMU: The Justiciability of Soft Law Measures Enacted by the ECB against the Financial Crisis before the European Courts', 37(1) Yearbook of European Law 626-649 (2018).

${ }^{81}$ Criticizing the inadequacy of present accountability rules in view of the important political role played by the ECB during the recent financial crisis, see Chris Land, 'The Eurozone Crisis and the European Central Bank's Lost Independence', 25 Minnesota Journal of International Law 483-518 (2016).

82 Judgment of the CJEU of 27 November 2012, Pringle, C-370/12, 158-165. See Luis M. Hinojosa Martínez, 'La compatibilidad del Mecanismo Europeo de Estabilidad con el Derecho europeo: jurisprudencia para tiempos de crisis', in Diego J. Liñán (Ed.), Las Crisis Políticas y Económicas: Nuevos Escenarios Internacionales (Tecnos 2014) 212-238.

${ }^{83}$ Christophe Blot/Paul Hubert/ Fabien Labondance, 'Reforming the European Central Bank', in Jérôme Creel/ Éloi Laurent/ Jacques Le Cacheux (Eds), Report on the State of the European Union, Volume 5: The Euro at 20 and the Futures of Europe (Palgrave 2018) 83-96. 
In democratic countries, the management of prudential supervision is usually more linked to the executive power and subject to more parliamentary control mechanisms than the monetary policy. Thus the accountability of ECB's organs in the field of prudential supervision is enhanced but their decision-making process is still kept insulated from external political intrusion. ${ }^{84}$ At the end of the day, it is the Governing Council of the ECB (the supreme and independent monetary authority) that takes the definitive decisions also in the ambit of supervision. Nevertheless, as a question of principle, the ECB (more directly, its Supervisory Board) is accountable to the European Parliament and the Council in this domain. 85 Besides, the possibility that national Parliaments invite the Chair or a member of the Supervisory Board to participate in an exchange of views in relation to the supervision of credit institutions in that member state is undoubtedly a striking novelty in the EU's conception of accountability. ${ }^{86}$

\section{Case Studies of Financial Reform: Their Incidence on Distributional Policies}

The purpose of this section is to analyze some examples of recent regulatory reform in Europe as a response to the financial crisis to check out if they have eroded the European social model and betrayed the promises that accompanied their presentation or, on the contrary, they have improved the regulation of financial markets making them more stable while enhancing the protection of taxpayers and consumers and generating positive distributional effects. As it would be impossible to analyze in detail all the huge legislative effort that the EU has recently developed in the financial field, we have chosen three of the most emblematic and 'revolutionary' European reforms to perform this evaluation.

\footnotetext{
84 The reporting obligations of the ECB in the field of supervision are similar to those on monetary matters. Additionally, the ECB is obliged to answer orally or in writing to questions put to it by the European Parliament or by the euro Group. The Chair of the Supervisory Board can be asked to take part in confidential oral discussions behind closed doors with the Chair and Vice-Chairs of the competent committee of the European Parliament. This Institution also has to approve the nomination of the Chair and Vice-Chair of the ECB's Supervisory Board. After the appointment, the Council by qualified majority may remove them from office, but this can only be done following a proposal of the ECB and with the approval of the European Parliament (Articles 20, 26(4) of Council Regulation (EU) No 1024/2013 of 15 October 2013 conferring specific tasks on the European Central Bank concerning policies relating to the prudential supervision of credit institutions, OJ L 287, 29 October 2013, p. 63-89 [SSM Regulation]). An Interinstitutional Agreement has been concluded between the ECB and the European Parliament organising their relationship (Interinstitutional Agreement between the European Parliament and the ECB on the practical modalities of the exercise of democratic accountability and oversight over the exercise of the tasks conferred on the ECB within the framework of the Single Supervisory Mechanism, OJ L 320, 30 November 2013, p. 1).

${ }^{85}$ Article 20(1) SSM Regulation. See Fabian Amtenbrink/ Menelaos Markakis, 'Towards a Meaningful Prudential Supervision Dialogue in the Euro Area? A Study of the Interaction Between the European Parliament and the European Central Bank in the Single Supervisory Mechanism', (1) European Law Review 3-23 (2019).

86 Article 21 SSM Regulation. Warning against the clash of legitimacies that may appear when the European supervisory authority explains decisions taken in the general 'interest of the Union as a whole' (Article 19(1) SSM Regulation) confronting potential conflicting arguments by national MPs who just defend the national interest see Hinojosa-Martínez, supra n. 74 at 63-64.
} 


\subsection{The Recovery and Resolution of Banks}

The Bank Recovery and Resolution Directive (BRRD) ${ }^{87}$ entered into force in 2014 promising that credit institutions would not continue privatizing earnings in prosperous times while they socialized losses when crises arrive. This Directive introduced several measures to achieve this objective:

a) A system of early intervention that could involve, among other things, taking over the management of these institutions and appointing a temporary administrator ${ }^{88}$ if this could prevent a more costly operation of recovery or resolution (when the situation has worsened and the credit institution is no longer viable). ${ }^{89}$

b) Before injecting any public money in a troubled bank, a bail-in procedure is triggered so that its shareholders and creditors are the first to lose their money to absorb the losses. ${ }^{90}$ Non-guaranteed deposits over $100.000 €$ could also be called in to cover the restructuring costs if it is necessary in exceptional circumstances. No public funding can be provided for the resolution until the shareholders and the holders of other instruments of ownership contribute to loss absorption with no less than $8 \%$ of the undertaking's total liabilities. ${ }^{91}$ In any case, member states 'may exclude or partially exclude certain liabilities from the' bail-in, inter alia to avoid contagion to other institutions or a destruction in value that 'would be higher than if those liabilities were excluded from bail-in' if the Commission does not object. ${ }^{92}$ Covered deposits are always fully protected.

c) National resolution funds have been created on the basis of the contributions of credit institutions and investment undertakings. ${ }^{93}$ They could provide the additional funds needed to restructure any of these firms with the strict limits established in BRRD (e.g. the financing cannot exceed $5 \%$ of the bank's total liabilities) and always respecting EU state aids rules. Nevertheless, member states can provide additional funding for these operations in the very extraordinary situation of a systemic crisis' through the use of government funds after the abovementioned $8 \%$ bail-in has been applied and if the Commission considers the operation compatible with EU state aids regulation. ${ }^{94}$

\footnotetext{
${ }^{87}$ Directive 2014/59/EU of the European Parliament and of the Council of 15 May 2014 establishing a framework for the recovery and resolution of credit institutions and investment firms (OJ L 173, 12.6.2014, p. 190-348).

88 E.g. ECB, ECB appoints temporary administrators for Banca Carige, Press release, 2 January 2019, available

https://www.bankingsupervision.europa.eu/press/pr/date/2019/html/ssm.pr190102.en.html.

On 8 January 2019, Italy's government provided state guarantees of a nominal value of 3 billion euros in order to facilitate a capital increase (Decreto-Legge, Misure urgenti a sostegno della Banca Carige S.p.a. - Cassa di risparmio di Genova e Imperia (19G00002) (GU Serie Generale n.6 del 8 January 2019)).

${ }^{89}$ Articles 27-30 BRRD.

${ }^{90}$ Article 34 BRRD.

${ }^{91}$ Article 37 BRRD.

92 Article 44(3) and (12) BRRD. Nicola Ruccia, 'The Role of the Private Sector In Resolution for Banks', 57 Revista de Derecho Comunitario Europeo 615-640 (2017) 627-629.

${ }_{93}$ Article 100 BRRD.

${ }^{94}$ Article 37(10) BRRD.
} 
Additionally, a Single Resolution Mechanism (SRM) ${ }^{95}$ was established for the member states participating in the Banking Union, together with the creation of a Single Resolution Fund (SRF). ${ }^{96}$ The SRM sets the procedure to be followed for the resolution of banks either subject to the SSM or whose resolution scheme requires the use of the SRF. The SRM respects the BRRD and has involved the creation of a Single Resolution Board (SRB). When a bank is identified as failing or likely to fail, the SRB must decide if a private sector solution is possible and, in the negative, whether it is in the public interest to initiate a resolution procedure. When it decides that it is not in the public interest to do so, the Bank will be wound up in accordance with the applicable national law. However, if the SRB decides that it is in the public interest to resolve the bank, it adopts a resolution scheme that is transmitted to the Commission. As a European agency the SRB cannot make discretional policy choices and therefore its resolution schemes need to be endorsed by the Commission. ${ }^{97}$ In some cases the Commission is obliged to ask the Council to approve its amendments to the SRB's proposal. ${ }^{98}$ The whole procedure finishes in a maximum of 24 hours.

The establishment of objective parameters to trigger the intervention of credit institutions intends to incentivize their safe management (Articles 9 and 27 BRRD). The recovery and resolution plans pre-established for each institution also reduce the management's scope for action. The bail-in preference for failing institutions diminishes the moral hazard and increases the risk for shareholders and creditors promoting them to exercise a closer vigilance over the management actions (they will object to risky operations if the bank approaches the trigger parameters). Has this legislation definitively protected public finances against the burden of saving failing banks and investment firms thereby deviating the use of taxpayer's money from other social objectives?

There are two essential objectives embedded in the BRRD: the continuance of the critical functions of banks facing difficulties and the stability of the financial

\footnotetext{
${ }^{95}$ Regulation (EU) No 806/2014 of the European Parliament and of the Council of 15 July 2014 establishing uniform rules and a uniform procedure for the resolution of credit institutions and certain investment firms in the framework of a Single Resolution Mechanism and a Single Resolution Fund (OJ L 225, 30.7.2014, p. 1-90) (SRM Regulation).

${ }^{96}$ The doubts about the soundness of Article 114 TFEU as a solid legal basis for the establishment of the SRF led to a political consensus whereby an international agreement among the member states would be signed to regulate certain aspects of the contributions and the use of the Fund (Council of the EU, Agreement on the Transfer and Mutualisation of Contributions to the Single Resolution fund, Doc. 8457/14, 14 May 2014). See Federico Fabbrini, 'On Banks, Courts and International Law: The Intergovernmental Agreement on the Single Resolution Fund in Context', 21 Maastricht Journal of European and Comparative Law 444-463 (2014).

${ }^{97}$ If the Commission objects to the discretionary aspects of the resolution scheme, the SRB has to modify it accordingly in 8 hours and the scheme will be approved (Article 18(7) SRM Regulation).

98 If the Commission objects to the scheme because it does not consider it 'in the public interest' and the Council agrees with the Commission, the financial entity shall be wound up in accordance with the applicable national law. If the Commission objects to the scheme because it disagrees with the amount of the SRF to be used and the Council agrees with the Commission, the SRB has to modify the scheme accordingly in 8 hours and the scheme will be approved. However, if the Council refuses the Commission's objections in either of these two cases, the resolution scheme enters into force (Article 18(7) and (8) SRM Regulation).
} 
system. When problems arise, the ideal way out is of course to seek a market solution (to find a sound financial entity to buy the troubled undertaking), ${ }^{99}$ but this is usually difficult and will most often not possible, particularly in periods of general financial turmoil. When that is not feasible the narrative of the Directive clearly prioritizes the bail-in ${ }^{100}$ of failing credit institutions and it establishes various strict conditions before any public money can be used to recapitalize or restructure these undertakings. However, the BRRD leaves open certain bail-out options for anxious member states that find it less harmful to rescue a bank with public money than to wind it up assuming the blast wave of consequences. When a credit institution is still solvent but needs support because of the existence of 'serious disturbances' in the economy of a member state, 101 the latter can provide certain state guarantees (to facilitate the raising of capital) or even an injection of own funds or purchase of capital (Article 32(4) BRRD) subject to the approval of the Commission under the Union state aid framework ${ }^{102}$ as has happened with Monte dei Paschi di Siena. ${ }^{103}$

In the context of a resolution, Article 37(10) BRRD establishes that member states may provide public stabilization funds for equity support or assume the temporary public ownership of a credit entity in situations of 'systemic crisis', although they need the approval of the Commission under the Union state aid framework. To make this compatible with the BRRD some additional conditions have to be met, ${ }^{104}$

\footnotetext{
${ }^{99}$ The Resolution of Banco Popular and its subsequent acquisition by Banco Santander was the first case of application of this market solution under the new system and was presented by the European authorities as an example of the fulfillment of the SRM objectives: no use of public money and maintenance of the critical functions of the troubled bank. However, more than 100 legal actions have been lodged at the international, European and national level in what will be a long legal battle that may condition the future configuration of the resolution regime in the EU. Nevertheless, the General Court has taken a restrictive approach towards the recognition of compensation to individuals prejudiced by the resolution operations (Judgments of the General Court of 13 July 2018, Chrysostomides, T-680/13 and Bourdouvali, T-786/14). Banco Santander declared one year later that the acquisition of Banco Popular had finally involved 12.000 million euros losses for the former.

${ }^{100}$ Bart P.M. Joosen, 'Bail-In Mechanisms in the Bank Recovery and Resolution Directive', in Saskia M.C. Nuijten/ Bart P.M. Joosen/ Patrick Clancy, The Bank Recovery and Resolution Directive and the Single Resolution Mechanism (Eleven International Publishing 2017) 23-46.

101 Article 32(4) BRRD establishes additional conditions to this precautionary public support: it must be temporary, it cannot be used to offset losses, it must be proportionate to the disturbances in the state economy, etc. Besides, the injection of own funds or purchase of capital instruments must be done at prices and on terms that do not confer an advantage upon the financial institution (World Bank, Understanding Bank Recovery and Resolution in the EU: A Guidebook to the BRRD, (World Bank 2017) 67-72, available at http://pubdocs.worldbank.org/en/609571482207234996/FinSAC-BRRD-Guidebook.pdf).

102 Maria Rosaria Miserendino, 'State Aid for the Banking Sector: What Has Changed after the New BRRD and SRM Regulation', 2018 European State Aid Law Quarterly 204 (2018).

${ }^{103}$ European Commission, Commission authorises precautionary recapitalisation of Italian bank Monte dei Paschi di Siena, Press Release, 4 July 2017.

${ }^{104}$ As already said, the shareholders, the holders of other instruments of ownership or capital, and the other eligible liabilities must have contributed to loss absorption with no less than $8 \%$ of the entity's total liabilities.
} 
but the fact is that they do not block the path towards the bail-out of banks under resolution. 105

An additional way to justify the disbursement of state public funds consists of the declaration that the bank's resolution is not in the public interest (for example, because that entity lacks systemic importance) and then it is referred to a liquidation procedure under national law. In that case, public authorities may provide financial support if they obtain the Commission's placet under the Union state aid rules. ${ }^{106}$ The decision that determines whether it is in the public (European) interest to resolve a bank or it has to be liquidated according to national law implicates assessing many complex elements and involves some margin of discretion. The greater closeness of the national authorities to those directly affected by the resolution will undoubtedly influence their willingness to be more generous with the public help offered to soften the operation. A further element of distortion stems from the lack of harmonization of national insolvency regimes. ${ }^{107}$ Thus the European procedure for insolvent banks needs to be finetuned to avoid accusations of applying double standards. ${ }^{108}$

The contagion between failing banks' debt and sovereign debt has been alleviated and the SRM seems to have increased the resilience of the European financial

105 Francesco Seatzu, 'The Current Italian Banking Crisis: An Ultimate Litmus Test for Measuring the Growing Mood of Euro-Skepticism in the "Belpaese"?', 42 Revista General de Derecho Europeo (2017), available at https://www.iustel.com//v2/revistas/detalle_revista.asp?id_noticia=418726\&. 106 This has been the case of the liquidation of Banca Populare de Vicenza and Veneto Banca in Italy in 2017. This process raised accusations of discrimination in relation to the treatment given to Banco Popular in Spain. The Italian government pumped 4.785 million euros (with a potential involvement in state guarantees of up to 12.000 million euros) in an operation to sell to Intesa Sanpaolo the solvent activities of these two entities while locating the rest of their operations in a bad bank created to that effect. Senior debt holders did not lose their money. The Commission considered that European state aid rules had been respected (European Commission, Commission approves aid for market exit of Banca Popolare di Vicenza and Veneto Banca under Italian insolvency law, involving sale of some parts to Intesa Sanpaolo, Press Realese, 25 June 2017). For a similar decision in the Cypriot context, see European Commission, Commission approves aid for financing the orderly market exit of Cyprus Cooperative Bank Ltd, involving sale of some parts to Hellenic Bank, Press Release, 19 June 2018.

107 The liquidation of ABLV Bank is particularly illustrative. On February 2018 the ECB declared that ABLV Bank and its subsidiary in Luxembourg were failing or likely to fail, and the SRB decided not to adopt a resolution scheme because it is not necessary in the public interest and referred the liquidation to Latvian law. However, on 9 March 2018, a Luxembourg Commercial Court decided not to place the Luxembourg subsidiary in liquidation because it considered it solvent, and appointed administrators to sell it to new investors. See J. Deslandes/ M. Magnus, Further Harmonising EU Insolvency Law from a Banking Resolution Perspective?, European Parliament, Doc. PE 614.514, April 2018, 2-3, available http://www.europarl.europa.eu/RegData/etudes/BRIE/2018/614514/IPOL_BRI(2018)614514_E N.pdf.

108 Denouncing the application of double standards when comparing the cases of Banco Popular with Banca Populare de Vicenza and Veneto Banca, see Luigi Scipione, 'La liquidación «ordenada» de los bancos del véneto: ¿hacia la quiebra de la nueva normativa europea?', 19532 La Ley 1-26 (2017), or the Cypriot cases Eleni Koumidou, 'Bail-In Nightmares: The Cypriot Bail-In Paradigm in the Light of the Italian and Spanish Cases', 15(2) European Company Law 43-50 (2018); Jorge Urbaneja Cillán, 'El régimen jurídico de la reestructuración y resolución de entidades de crédito. la compleja transposición al ordenamiento español de la normativa europea', 42 Revista General de Derecho Europeo 86-127 (2017) at 126. 
system. ${ }^{109}$ However, member states continue to use public money to rescue troubled financial institutions either because they think that it will be less costly for their budget or because they fear the political price of liquidation. While this reform limits the shameless spread of credit institutions' losses among the population, the social subsidization to the banking industry continues through the use of taxpayers' money in recovery and resolution schemes. ${ }^{110}$ If the public authorities are convinced that the injection of fresh money will reduce the cost of recovering/resolving banks they should justify it with credible data and explain it openly to the citizenship. The required funding should be made explicit in the configuration of the social contract and not pilfered in haste in emergency government meetings as if financial crises were always taking us by surprise.

\subsection{The Financial Transaction Tax (FTT)}

The FTT has its origin in a proposal from Nobel Prize James Tobin to disincentive purely speculative operations in the exchange markets. ${ }^{111}$ He proposed to levy a small tax on each transaction that would not deter long and medium-term operations but would significantly raise the cost of short-term transactions. This idea has gone through numerous developments and variations and has become one of the flagships of the anti-globalization movement. ${ }^{112}$ The idea of reducing purely speculative transactions that generate top-heavy financial markets, foster instability and provide no benefit for financing the real economy has found many followers. ${ }^{113}$ Apart from promoting a more stable environment, such a tax would contribute to make the financial markets pay for the social cost that their activities generate. Those that oppose the tax argue that it may negatively affect market liquidity, promote even greater instability and that it is likely to cause a delocalization of financial operations towards capital markets free from this burden. ${ }^{114}$

After the severe and enduring speculative attacks against the public debt of some member states in 2010-2011, the Commission made a first proposal in 2011 for

\footnotetext{
${ }^{109}$ See in that sense the revealing data provided by Giovanni Covi/ Ulrich Eydam, 'End of the sovereign-bank doom loop in the European Union? The Bank Recovery and Resolution Directive', Journal of Evolutionary Economics 1-26 (2018).

${ }^{110}$ Marco Bodellini, 'To Bail-In, or to Bail-Out, that is the Question', 19 European Business Organization Law Review 365-392 (2018).

111 James Tobin, 'A Proposal for International Monetary Reform', 4 Eastern Economic Journal 153159 (1978).

112 E.g. Association pour la Taxation des Transactions financières et pour l'Action Citoyenne (ATTAC) (https://www.attac.org/en/overview).

113 Vladimir N. Zuev/ Elena Y. Ostrovskaya, 'Socializing Global Economic Governance: Introducing a Financial Transaction Tax', 26(4) European Review 686-703 (2018); Eduardo Dávila, Optimal Financial Transaction Taxes, No 114 (2014) Meeting Papers from Society for Economic Dynamics, available at https://EconPapers.repec.org/RePEc:red:sed014:114; Joseph E. Stiglitz, 'Using Tax Policy to Curb Speculative Short-Term Trading', 3 Journal of Financial Services Research 101-115 (1989).

114 Jean-Edouard Colliard/ Peter Hoffmann, 'Financial Transaction Taxes, Market Composition, and Liquidity', 72(6) The Journal of Finance 2685-2716 (2017); Thornton Matheson, Taxing Financial Transactions: Issues and Evidence, IMF Working Paper No. 11/54 (2011), available at https://www.imf.org/external/pubs/ft/wp/2011/wp1154.pdf.
} 
the establishment of a FTT for the whole EU. ${ }^{115}$ However, the lack of agreement in the Council after lengthy discussions led 11 member states to request an enhanced cooperation for the harmonization of the tax only among those countries that trusted its benefits one year later. ${ }^{116}$ As a fiscal measure, unanimity was required for its approval (Article 113 TFEU) and this would have been impossible to achieve for the entire Union. After the enhanced cooperation was authorized ${ }^{117}$ the Commission presented a refurbished proposal on February 2013 that is still under discussion. ${ }^{118}$

The FTT proposed by the Commission would tax almost all financial instruments when traded by financial firms. However, among other exceptions, trade in primary markets and transactions relevant for citizens and non-financial businesses are excluded from the tax (to protect the financing of the productive economy). ${ }^{119} \mathrm{~A}$ general rate of $0.1 \%$ is envisaged for most financial products, but derivatives would bear just a $0.01 \%$ rate. ${ }^{120}$ Two main measures are proposed to avoid the duty's circumvention: a) when any party to the transaction is established in the participating members states, the operation is taxed even if it takes place outside the FTT-area (residence principle); b) all the transactions of financial products issued in the participating member states will be taxed even if the traders are not established in those countries (issuance principle). ${ }^{121}$

In any case, this initiative is stranded in the Council and does not have prospects of success for the time being. During the most painful moments of the financial crisis, the popular support for this type of duty made some governments think that this

\footnotetext{
115 Proposal for a Council Directive on a common system of financial transaction tax and amending Directive 2008/7/EC, Doc COM (2011) 594 final, 28 September 2011.

116 Today only 10 member states continue with the negotiations after Estonia decided to quit the enhanced cooperation: France, Germany Belgium, Portugal, Austria, Slovenia, Greece, Spain, Italy and Slovakia.

117 The UK questioned the legality of the enhanced cooperation alleging that it had extraterritorial effects and imposed costs on Member States which are not participating in this legislative procedure, but its action before the CJEU was dismissed basically on procedural grounds (judgment of the CJEU of 30 April 2014, UK v. Council, C-209/13). See also Bogdan Tasnadi et al., Financial Transaction Taxes in the European Union, European Commission Taxation Papers, Working Paper No 62, 2015, 11-13, available at https://www.steuer-gegenarmut.org/fileadmin/Dateien/Kampagnen-Seite/Unterstuetzung_Ausland/EU/2015-

2016/1602_EU_Commission.pdf.

118 Proposal for a Council Directive implementing enhanced cooperation in the area of financial transaction tax, Doc COM(2013) 71 final, 14 February 2013 (FTT proposed Directive). See JeanSébastien Pilczer, 'Le parcours contentieux de la coopération renforcée en matière de taxe sur les transactions financières: la bataille de l'autorisation est gagnée, celle de la mise en œuvre reste à mener', 50(3) Cahiers de droit européen 597-636 (2014); Federico Fabrini, 'Taxing and Spending in the Euro Zone: Legal and Political Challenges related to the Adoption of the Financial Transaction Tax', 2 European Law Review 155-175 (2014); Dieter Pesendorfer, 'Financial Taxes and the Sand in the Wheels of Financialization: Legal Challenges for the EU Directive Implementing Enhanced Cooperation in the Area of Financial Transaction Tax', 25(2) European Review of Public Law 619653 (2013).

${ }^{119}$ Also exempted from the FTT are Central Counter Parties, Central Securities Depositories, ECB, central banks of Member States, ESM and member states managing public debt (Article 3 FTT proposed Directive).

${ }^{120}$ Article 9 FTT proposed Directive.

121 Recital 15 and Articles 4 and 14 FTT proposed Directive.
} 
small tax could transmit the right symbolic message, ${ }^{122}$ without significant negative consequences for the attractiveness of their financial markets. However, the volatility and flexibility of capital markets (where transactions are easy to delocalize) and the pressure of the financial industry ${ }^{123}$ have sown doubt among the participating member states. ${ }^{124}$ The unanimity required has favored the blocking of the Directive several times by just one member state. ${ }^{125}$

The deadlock at the European level has led several member states to develop national FTTs. After a first unsuccessful experience in Sweden ${ }^{126}$, it would appear as if the Italian ${ }^{127}$ and French ${ }^{128}$ FTT could show the way to other European countries in the future. ${ }^{129} \mathrm{~A}$ common characteristic of these regimes is the limited number of operations covered and the modest amount of state revenues that they produce. The whole picture is thus very distant from the promises of the ambitious Commission's proposal of 'ensuring that financial institutions make a fair and substantial contribution to covering the costs of the recent crisis (...) and creating

122 Daniela A. Kroll/ Dirk Leuffen, 'Enhanced Cooperation in Practice. An Analysis of Differentiated Integration in EU Secondary Law', 23(3) Journal of European Public Policy 353-363 (2015) 363.

${ }^{123}$ Lisa Kastner, 'Business Lobbying under Salience - Financial Industry Mobilization against the European Financial Transaction Tax', 25(11) Journal of European Public Policy 1648-1666 (2018).

${ }^{124}$ The scope of application of this tax has been progressively reduced during the negotiations in the Council, but some member states insist on reducing it further (e.g. Belgium wants to exclude from the tax base pension funds and insurances). The destination of the tax revenues also engenders debate: some point towards a Eurozone budget while others prefer them to feed national budgets.

125 Belgium and Slovakia were blocking the agreement until April 2017 but since then only Belgium seems to oppose the adoption of the Directive (Marion Fontana, 'Paris et Berlin proposent de relancer la taxe sur les transactions financières sur le modèle français', Europe Daily Bulletin No. 12151, 4 December 2017).

${ }^{126}$ Sweden was a pioneer in the implementation of a FTT in 1984. However, after constant amendments, the regime was abrogated in 1991 because the revenues were disappointing and the distortions in the financial market very relevant (important shares' price drops and a dramatic fall in the volume of trade in bonds and futures markets). Most experts agree that the tax was easy to avoid and the regime promoted base erosion. See Steven R. Umlauf, 'Transaction Taxes and the Behaviour of the Swedish Stock Market', 32(2) Financial Economics 227-40 (1993).

127 In 2013 Italy introduced its FTT levying a duty on 3 different operations: purchase of shares and similar instruments $(0.1 \%$ or $0.2 \%$ depending on the transaction), derivatives, and cancelled or modified orders on high frequency trading (0.02\%). Giuseppe Cappelletti/ Giovanni Guazzarotti/ Pietro Tommasino, 'The stock market effects of a securities transaction tax: Quasi-experimental evidence from Italy', 31 Journal of Financial Stability 81-92 (2017).

128 The French FTT was introduced in 2012 and it covers the purchase of shares of French listed companies with a market capitalization above 1 billion euros $(0.2 \%)$, uncovered credit default swaps on sovereign debt $(0.01 \%)$ and cancelled orders in high-frequency trading $(0.01 \%)$. See the critical report of the Cour de comptes, La taxe sur les transactions financières et sa gestion, Ref. S2017-1860, 19 June 2017, available at https://www.ccomptes.fr/sites/default/files/201707/20170704-refere-S2017-1860-taxe-transactions-financieres-et-depenses-fiscales.pdf, and the criticism of Iryna Verizenko et al., 'The impact of the French financial transaction tax on HFT activities and market quality', 67 Economic Modelling 307-315 (2017); for a more positive perspective claiming that 'the French FTT might provide pathways for a reduction in volatility without severely affecting trading volumes or liquidity', see Sebastian Eichfelder/ Mona Lau/ Felix Noth, The impact of financial transaction taxes on stock markets: Short-run effects, long-run effects, and migration, arqus Discussion Paper, No. 228 (2018), available at https://www.econstor.eu/bitstream/10419/182540/1/1031254358.pdf.

129 In January 2019, the Spanish government sent to the national Parliament a bill to establish a FTT largely inspired in the French model. 
appropriate disincentives for transactions that do not enhance the efficiency of financial markets'.130

\subsection{The rules for the remuneration of financial executives}

The astronomic figures achieved by financial executives' salaries just before the 2008 crisis caused public indignation. Some irresponsible and at times misleading trading 131 that made a crucial contribution to market disruption had been rewarded with very generous bonuses based on short-term profits, independently of the long-term consequences of the transactions (not only for the economy but even for the financial firm involved). If salaries must reflect the social value generated by an economic activity, the criteria to determine financial executives' salaries had been clearly distorted and did not reflect the social welfare derived from their performance.

But apart from any moral considerations, the usual structure of this remuneration was found to be pro-cyclical and promoting financial bubbles and excessive risk. During the two decades preceding the 2008 crisis, a disproportionate growth of the variable pay (as compared to fixed pay) took place in the remuneration policies of financial executives. These incentives were usually calculated according to the short-term profit that they generated for their company. This wage system fostered risky (and sometimes purely speculative) transactions that produced big gains in the short-term regardless of the soundness of the operation and the longterm consequences for the financial firm involved. ${ }^{132}$ The crisis made it possible to find consensus in the EU to consider the remuneration policies a question of systemic relevance that needed to be regulated as part of the risk evaluation of undertakings participating in the capital markets.

Based on the 'Principles for Sound Compensation Practices' issued by the FSF (later FSB) in 2009,133 the Commission produced a Recommendation on the remuneration of directors of listed companies. ${ }^{134}$ The following year what is known as the Capital Regulation Directive III (CRD III) ${ }^{135}$ would introduce some of the rules in force today to legally frame the remuneration of financial executives in

\footnotetext{
130 Doc. COM (2013) 71 final, supra n. 118 at 2.

${ }^{131}$ Better Finance, A Major Enforcement Issue: the Mis-Selling of Financial Products, Briefing Paper, $\begin{array}{lc}\text { April } & \text { 2017, } \\ \text { http://betterfinance.eu/fileadmin/user_upload/documents/Research_Reports. }\end{array}$

132 For a review of the economic literature debating on the real influence of the financial firms executives' pay structure on the management of risks, see Andenas/Chiu, supra n. 60, 360-366.

${ }^{133}$ Available at http://www.fsb.org/wp-content/uploads/r 0904b.pdf. In 25 September 2009, the same body issued the 'Implementation Standards for the FSB Principles for Sound Compensation Practices' available at http://www.fsb.org/2009/09/principles-for-sound-compensation-practicesimplementation-standards/.

134 Commission Recommendation 2009/385/EC of 30 April 2009 complementing Recommendations 2004/913/EC and 2005/162/EC as regards the regime for the remuneration of directors of listed companies (OJ L 120, 15 May 2009, pp. 28-31).

135 Directive 2010/76/EU of the European Parliament and of the Council of 24 November 2010 amending Directives 2006/48/EC and 2006/49/EC as regards capital requirements for the trading book and for re-securitisations, and the supervisory review of remuneration policies (OJ L 329, 14 December 2010, p. 3-35).
} 
credit institutions and investment firms. ${ }^{136}$ This regime would subsequently be refined in the Capital Requirements Directive IV (CRD IV) ${ }^{137}$ and the Capital Requirements Regulation (CRR),138 and developed in the 'Guidelines on Sound Remuneration Policies' issued by EBA in December 2015. 139

This regime has a systemic purpose (reducing the incentives for excessive risk taking to foster long-term welfare maximization) and therefore credit institutions and investment firms must apply it to all categories of staff 'whose professional activities have a material impact on their risk profile'. ${ }^{140}$ Article 94 CRD IV regulates the variable element of the salary. Essentially, it is established that the variable component shall not exceed $100 \%$ of the fixed component of the total remuneration of these executives. Exceptionally, a qualified majority of shareholders may authorize a higher percentage of the variable salary if it does not exceed $200 \%$ of the fixed salary. ${ }^{141}$ At least $50 \%$ of the variable remuneration shall consist of shares or share-linked instruments and at least $40 \%$ of the variable remuneration (or $60 \%$ when the variable salary is particularly high) will be deferred over a period between 3 and 5 years. The deferred variable remuneration must be adaptable to reflect a potential negative performance of the financial firm and the total sum of variable remunerations cannot limit the ability of the institution to strengthen its capital base. Besides, discretionary pension benefits will be subject to a five-year retention period so that they are adapted to the longterm financial health of the undertaking.

Apart from the quantitative and qualitative limits on remuneration, CRD IV reinforced the control mechanisms of remuneration policies ${ }^{142}$ and CRR established enhanced obligations of transparency. ${ }^{143}$

\footnotetext{
136 The Commission has recently proposed that only investment firms of systemic importance be subject to this remuneration regime in the future sponsoring the establishment of less onerous rules for smaller firms (Proposal for a Directive of the European Parliament and of the Council on the prudential supervision of investment firms and amending Directives 2013/36/EU and 2014/65/EU, Doc. COM (791) final, 20 December 2017).

${ }^{137}$ Directive 2013/36/EU of the European Parliament and of the Council of 26 June 2013 on access to the activity of credit institutions and the prudential supervision of credit institutions and investment firms (OJ L 176, 27 June 2013, p. 338-436).

${ }^{138}$ Regulation (EU) No 575/2013 of the European Parliament and of the Council of 26 June 2013 on prudential requirements for credit institutions and investment firms (OJ L 176, 27 June 2013, p. 1337).

${ }^{139}$ EBA, Guidelines on sound remuneration policies under Articles 74(3) and 75(2) of Directive 2013/36/EU and disclosures under Article 450 of Regulation (EU) No 575/2013, Doc. EBA/GL/2015/22, 21 December 2015.

${ }^{140}$ Article 92 CRD IV. See also Commission Delegated Regulation (EU) No 604/2014 of 4 March 2014 supplementing Directive 2013/36/EU of the European Parliament and of the Council with regard to regulatory technical standards with respect to qualitative and appropriate quantitative criteria to identify categories of staff whose professional activities have a material impact on an institution's risk profile (OJ L 167, 6 June 2014, p. 30-35).

${ }^{141}$ This remuneration must be supported by 'at least $66 \%$ [of the shareholders/owners] provided that at least $50 \%$ of the shares or equivalent ownership rights are represented or, failing that, [the remuneration needs to be authorized] by a majority of $75 \%$ of the ownership rights represented' (Articl4 94(1)(g)(ii) CRD IV).

142 E.g. Article 92(2) CRD IV requires an annual independent internal review of remuneration policies and the staff engaged in these control functions must be independent from the business units they oversee.
} 
Convinced of the beneficial systemic effects of this remuneration policy and of the convenience of establishing a coherent regulation throughout the different segments of the financial market, the EU has extended this regime to asset managers with some adaptations. Noticeably, the fixed and the variable components of total remuneration must be 'balanced' but there is no maximum percentage of variable salary in proportion to the fixed salary; the period that a percentage of the variable remuneration is deferred may also be different. ${ }^{144}$ Additionally, rules on remuneration governance have also been instituted for insurers, but they are slightly more flexible than for credit institutions and asset managers. ${ }^{145}$ Finally, Directive $2017 / 828$ provides for an enhanced control of the remuneration policies by shareholders of all listed companies registered in a member state and operating in an EU regulated market. ${ }^{146}$

In a refinement of this policy and in order to improve the protection of consumers, the EU has also regulated the salary of the staff providing retail banking services or selling insurance contracts to avoid productivity incentives that would foster practices that go against the client's best interests. ${ }^{147}$

The rules governing the remuneration policy of credit institutions and investment firms under CRD IV and CRR entered into force in 2014 and it is now possible to evaluate their result after several years. At the beginning, EBA had to eradicate

\footnotetext{
${ }^{143}$ Among other things, they must make public the ratios between fixed and variable remuneration or the number of individuals being remunerated by EUR 1 million or more per financial year (Article 450 CRR).

${ }^{144}$ See Article 13 and Annex II of Directive 2011/61/EU of the European Parliament and of the Council of 8 June 2011 on Alternative Investment Fund Managers (OJ L 174, 1 July 2011, p. 1-73), and the 'Guidelines on sound remuneration policies under the AIFMD' published by ESMA 2013 (Doc. ESMA/2013/232) and amended in 2016 (Doc. ESMA/2016/579). See also Directive 2014/91/EU of the European Parliament and of the Council of 23 July 2014 amending Directive $2009 / 65 /$ EC on the coordination of laws, regulations and administrative provisions relating to undertakings for collective investment in transferable securities (UCITS) as regards depositary functions, remuneration policies and sanctions (OJ L 257, 28.8.2014, p. 186-213) and the 'Guidelines on sound remuneration policies under the UCITS Directive' (Doc. ESMA/2016/575, 14 October 2016).

${ }^{145}$ Articles 275 and 294 of Commission Delegated Regulation (EU) 2015/35 of 10 October 2014 supplementing Directive 2009/138/EC of the European Parliament and of the Council on the taking-up and pursuit of the business of Insurance and Reinsurance (Solvency II) (OJ L 12, 17 January 2015, p. 1-797), and guidelines 9 and 10 of the 'Guidelines on System of Governance' issued by EIOPA (Doc. EIOPA-BoS-14/253, 14 September 2015).

${ }^{146}$ Articles 9a and 9b of Directive (EU) 2017/828 of the European Parliament and of the Council of 17 May 2017 amending Directive 2007/36/EC as regards the encouragement of long-term shareholder engagement (OJ L 132, 20.5.2017, p. 1-25) (Lucia Ana Tomic/ Marko Zunic/ Suzana Audic Vuletic, 'Upcoming Challenges on Regulating Remuneration of the Directors and Implementing Remuneration Policies', V(2) Journal for International and European Law 323-344 (2018).

${ }^{147}$ Article 24(10) of Directive 2014/65/EU of the European Parliament and of the Council of 15 May 2014 on markets in financial instruments and amending Directive 2002/92/EC and Directive 2011/61/EU (OJ L 173, 12 June 2014, p. 349-496), and Article 17 of Directive (EU) 2016/97 of the European Parliament and of the Council of 20 January 2016 on insurance distribution (OJ L 26, 2 February 2016, p. 19-59).
} 
some tricks ${ }^{148}$ put in practice in certain entities to circumvent the variable remuneration limit and the UK unsuccessfully challenged the legality of the bonus cap before the CJEU. ${ }^{149}$ The reports published by EBA since 2014 show that the number of high earners (those awarded 1 million euros or more in annual remuneration) has increased or decreased slightly depending on the fluctuation between the euro and the pound sterling each year. ${ }^{150}$ However, there has been a constant decline in the percentage of variable remuneration in the total amount of salary since the entry into force of this policy. ${ }^{151}$ In sum, we have not seen a delocalization of activities taking into account that the EU enforces one of the strictest regimes of wage control in the financial sector in the global context. ${ }^{152}$ Pay levels have not been reduced but the structure of the remuneration has changed very significantly because financial firms have substantially increased the fixed component of the salary to keep their attractiveness for high executives when compared to other sectors of the economy.

Since the objective of the reform was not reducing in quantitative terms the level of remuneration in financial firms but fostering the stability of the financial system (by discouraging excessive risk taking), this regulatory regime can be qualified as successful. Shareholders have more interest and improved instruments to control the salary of financial executives, ${ }^{153}$ the supervisory authorities obtain better

148 EBA issued an Opinion on 15 October 2014 discarding the consideration of role-based or market value allowances as part of the fixed component of the remuneration, among other clarifications (39 banks had not made correctly the calculation of the fixed salary). The definitive version of the Guidelines would be published in December 2015 (supra n. 139).

149 The UK questioned the legality of this regime on several grounds that were dismissed by Advocate General Niilo Jääskinen in its Opinion of 20 November 2014, United Kingdom v. European Parliament and Council, C-507/13. The UK withdrew its application immediately after this Opinion. 150 The UK is by far the country with more executives earning above 1 million euros and most of them are paid in pounds sterling. The exchange effect increased the number of millionaires when the pound appreciates vis a vis the euro and vice versa. They were 3.178 in 2013, 3.865 in 2014 , 5.142 in 2015, 4.597 in 2016, and 4.859 in 2017 (EBA Report on High Earners, 11 March 2019, 4, available

https://eba.europa.eu/documents/10180/2551996/Report+on+High+Earners+2017.pdf).

151 The average of the variable component of the salary in relation to the fixed component for those earning EUR 1 million or more in annual remuneration was 317\% in 2013 (when there was no bonus cap), $127 \%$ in 2014, 118\% in 2015, 104\% in 2016, and 101\% in 2017 (EBA Report on High Earners, supra n. 150 at 8).

152 The Obama Administration renounced establishing quantitative limits on the remuneration of financial executives in the USA and the Dodd-Frank Act (Dodd-Frank Wall Street Reform and Consumer Protection Act [Pub.L. 111-203, 21 July 2010, H.R. 4173], available at https://www.govinfo.gov/content/pkg/PLAW-111publ203/html/PLAW-111publ203.htm) only provides for certain procedural rules to improve financial institutions governance, such as the requirement to hold a non-binding shareholder advisory vote on the executives' compensation programs, the creation of a board compensation committee whose members meet the independence standards set up by the Securities and Exchange Commission, and the implementation of compensations recovery measures in certain circumstances (Steven E. Kaplan/ Valentina L. Zamora, 'The Effects of Current Income Attributes on Nonprofessional Investors' Sayon-Pay Judgments: Does Fairness Still Matter?', 153(2) Journal of Business Ethics 407-425 (2018); Sam Liu, The Impact of the Dodd-Frank Act on Executive Compensation (31 January 2012), available at SSRN: https://ssrn.com/abstract=1996257).

153 However, practice shows that shareholders very rarely question executives' remuneration policies, and only do it in cases of bad economic performance of the financial firm (Jill Fisch/ Darius Palia/ Steven Davidoff Solomon, 'Is Say on Pay All about Pay: The Impact of Firm Performance', 8 Harvard Business Law Review 101-130 (2018)). 
information and the remuneration regime fosters financial stability. Nevertheless, shifting the variable component of the remuneration to fixed salary with the semiautomatic consent of the shareholders in times of bonanza does not necessarily improve risk management. ${ }^{154}$ At the end of the day, shareholders seek to maximize their profit and their interest in promoting financial stability is more mediated. ${ }^{155}$ The measures that defer the enjoyment of allowances and that adapt them to the long-term performance of the firm have more influence on the risk-taking decisions of financial executives than the variable salary cap. Besides, remuneration in this sector keeps on being inflated because it does not reflect the cost of the implied social insurance provided by the state both in recovery and resolution procedures and when the central banks provide very cheap liquidity to incentivize loans and investments that benefit the productive economy. ${ }^{156}$

\section{Conclusions}

The reaction to the 2008 financial crisis in the EU has been based on ordoliberalism. The objective of keeping competitive financial markets and improving their stability was addressed through a meritorious legislative and institutional effort that has significantly increased state intervention in those markets to reduce moral hazard. This normative production was accompanied by promises to end the socialization of losses when financial institutions got into trouble. The popular indignation against the strain of resources dedicated to save financial firms (and deviated from other goals) received in this sense a certain response.

However, the normative examples evaluated in this chapter show the shortcomings of this regulatory effort. The drafters of these norms have prioritized financial stability over the articulation of instruments that generate fairer distributional effects. ${ }^{157}$ The financial lobby has worked efficiently to block those aspects of reforms that could challenge the status quo more severely and damage the privileges of market participants over the rights of consumers and third parties. This has been facilitated by the traditional distance between financial rulemakers and the mechanisms of democratic control, a phenomenon that also affects the European normative production. Groups of deceived citizens are turning to extremist political parties that capitalize their discontent after years of austerity measures and that work to delegitimize the European integration process with nationalist populist demagogy.

\footnotetext{
${ }^{154}$ Andreas Kokkinis, 'Exploring the Effects of the Bonus Cap Rule: The Impact of Remuneration Structure on Risk-Taking by Bank Managers', 19(1) Journal of Corporate Law Studies 167-196 (2019).

155 Okamoto and Edwards have explained that it is impossible for the state to determine through regulation the optimal risk taking for financial enterprises (Karl S. Okamoto/ Douglas 0. Edwards, 'Risk-Taking', 32 Cardozo Law Review 159 (2010)).

${ }^{156}$ Dominic Quint/ Oreste Tristani, Liquidity provision as a monetary policy tool: the ECB's nonstandard measures after the financial crisis, ECB Working Paper Series No. 2113, November 2017.

157 John G. Glenn, Foucault and Post-Financial Crises. Governmentality, Discipline and Resistance (Palgrave 2019) 121-151; Pieter Van Cleynenbreugel, 'Typologies of solidarity in EU Law: A NonShifting Landscape in the Wake of Economic Crises', in Andrea Biondi et al., Solidarity in EU Law. Legal Principle in the Making (Edward Elgar 2018) 13-37.
} 
The EU must defeat the perception that it imposes a form of governance that has been described as 'executive federalism' 158 or even 'authoritarian manageralism'.159 The European integration process faces at present an existential crisis and is in urgent need of social re-legitimation. In order to achieve it, reinforcement of the democratic control of the financial normative output seems advisable, namely through an enhanced role for the European Parliament. If established institutions do not adequately respond to widely shared popular demands, the people end up questioning and replacing the institutions.

The construction of efficient and coherent European capital markets cannot be achieved at the expense of the citizenry. Insofar as the bulk of social policy remains in the hands of member states, economic and monetary union and single market rules must respect the social choices behind the redistributive policies designed at the national level. In addition, the reinforcement of consumers' rights and retail investors' protection in the financial market could have a very beneficial result, 160 not only transmitting the benefits of a well-functioning market to the population, but also increasing the trust of households in the capital market (thereby augmenting the influx of money and consequently its depth and liquidity). ${ }^{161}$ Consumer protection rules play in the market context a similar function as political and civil rights in the democratic context.

Today there is a clear public awareness of the distributional effects of financial markets' regulation and of its impingement on the social model. ${ }^{162}$ The EU must lead normative innovation in the reform of financial markets reinforcing those elements that allow recognizing it as a social market economy. It is a complex task because normative novelties must be compatible with an efficient functioning of the financial markets. Robust capital markets are necessary to uphold a competitive productive economy, and the latter is indispensable to sustain the European social model. The introduction of a financial transaction tax, or the regulation of financial executives' remuneration, are positive steps in the right direction that may differentiate Europe from other parts of the world as regards the impact of financial markets' regulation on the social model. The partial bail-in

\footnotetext{
158 Jürgen Habermas, The Crisis of the European Union - A Response (Polity Press 2012) 119.

159 Michael A. Wilkinson, 'Authoritarian Liberalism in the European Constitutional Imagination: Second Time as Farce?', 21(3) European Law Journal 313 (2015) 330.

${ }^{160}$ See the Communication from the Commission 'Consumer Financial Services Action Plan: Better Products, More Choice', Doc COM (2017) 139 final, 23 March 2017. In parallel, the Capital Markets Union includes among its objectives improving the access to retail investment products (European Commission, Distribution Systems of Retail Investment Products across the European Union (2018), available at https://ec.europa.eu/info/publications/180425-retail-investment-productsdistribution-systems_es). See also Niamh Moloney, 'EU Financial Market Governance and the Retail Investor: Reflections at an Inflection Point', 37(1) Yearbook of European Law 251-304 (2018). For a more general critique of what they consider an artificial discourse of the Commission in this field see Katalin Cseres/ Annette Schrauwen, 'Empowering Consumer-Citizens: Changing Rights or Merely Discourse?', in Dagmar Schiek (Ed.): The EU Economic and Social Model in the Global Crisis (Routledge 2013) 117-140.

161 Steve N. Isser, Maximization of Long-Term Consumer Surplus Is the Optimal Economic Policy (May 15, 2018), available at SSRN: https://ssrn.com/abstract=3178768 or http://dx.doi.org/10.2139/ssrn.3178768.

162 See for example the different ways in which central bank policy may affect inequality in Dietsch, supra n. 17, 237-243.
} 
Pre-print version

of troubled credit institutions and financial firms is also a necessary measure, but further research is needed to establish transparent and objective criteria to determine the degree of bail-in and bail-out to be applied in each operation.

This European leadership in the reform of capital markets, if exercised, would give arguments to those who advocate that, for the time being, the EU constitutes the best showpiece for a future cosmopolitan and solidarity market economy in the context of globalization. 